RUNNING HEAD: Personality, Flexibility and Well-Being

Accepted for publication in "Experimental Aging Research"

Note: This is an uncorrected version of an author's manuscript accepted for publication. Copyediting, typesetting, and review of the resulting proofs will be undertaken on this manuscript before final publication. During production and pre-press, errors may be discovered that could affect the content.

Flexibility as a Mediator Between Personality and Well-Being in Older and Younger Adults:

Findings from Questionnaire Data and a Behavioural Task

Priska Steenhaut* ${ }^{1-2}$, Gina Rossi ${ }^{2}$, Ineke Demeyer ${ }^{1} \&$ Rudi De Raedt ${ }^{1}$

${ }^{1}$ Department of Experimental Clinical and Health Psychology, Ghent University.

${ }^{2}$ Department of Clinical and Lifespan Psychology, Vrije Universiteit Brussel

Word count inclusive of title, main text, references, table titles, and figure captions: 7593

*Correspondence concerning this article should be addressed to Priska Steenhaut, e-mail:

Priska.Steenhaut@vub.be

The Version of Record of this manuscript has been published and is available in Experimental Aging Research, 2020, http://www.tandofline.com/ doi 10.1080/0361073X.2020.1805935 
RUNNING HEAD: Personality, Flexibility and Well-Being

\begin{abstract}
Background. Personality is a predictor of subjective well-being in older and younger adults, but less is known about the underlying mechanisms. One possible mechanism is psychological flexibility, which is the ability to keep an open mindset in order to make flexible choices adapted to the situation at hand.
\end{abstract}

Methods. We recruited 60 younger and 60 older adults and measured personality and well-being by questionnaires. To assess psychological flexibility we used questionnaires and a behavioral task assessing flexibility in information acquisition when making choices.

Results. Based on indirect effect analysis of the questionnaire data, in line with former research our data show that in both age groups, the relationship between personality and well-being runs through psychological flexibility.

Conclusion. This implies that training psychological flexibility may be a promising approach to increase well-being in both older and younger adults. This effect could not be demonstrated with our choice flexibility task, thus more research is needed to uncover why this could not be measured at the behavioral level.

Keywords: older adults; personality; psychological flexibility; experimental; well-being 
RUNNING HEAD: Personality, Flexibility and Well-Being

\section{Flexibility as a Mediator Between Personality and Well-Being in Older and Younger Adults: Findings from Questionnaire Data and a Behavioural Task}

Personality is a well-established predictor of well-being in both older and younger adults (e.g. Gutierrez, Jimenez, Hernandez, \& Puente, 2005; Harris, Brett, Starr, Deary, \& Johnson, 2016). However, less is known about the mechanisms through which it exerts its influence. One possible mechanism is psychological flexibility, which is the ability to keep an open and accepting mindset in order to be able to flexibly choose the option that is consistent with one's own values and that is adaptive to the situation (Hayes, Luoma, Bond, Masuda, \& Lillis, 2006; Kashdan \& Rottenberg, 2010). Several studies have found significant relationships between personality and psychological flexibility in younger adults (e.g. Latzman \& Masuda, 2013) and between psychological flexibility and subjective well-being in younger and older age groups (e.g. Brinkborg, Michanek, Hesser, \& Berglund, 2011; Scott, Daly, Yu, \& McCracken, 2017). Moreover, in a previous study, based on selfreport questionnaires, we could demonstrate an indirect influence of personality on well-being through psychological flexibility in both younger and older adults (Steenhaut, Rossi, Demeyer \& De Raedt, 2019). Neuroticism, extraversion, and conscientiousness are the three Big Five personality traits with the most consistent and strongest relationships with both psychological flexibility and well-being. Studies in younger adult samples have shown significant positive correlations between psychological flexibility and extraversion (Gámez, Chmielewski, Kotov, Ruggero \& Watson, 2011; Gloster, Klotsche, Chaker, Hummel \& Hoyer, 2011) and conscientiousness (Bond, Lloyd, \& Guenole, 2013; Gámez et al., 2011; Gloster, et al., 2011; Latzman \& Masuda, 2013), whereas neuroticism has been inversely related to psychological flexibility (Bond et al.,2013; Gámez et al., 2011; Gloster, et al., 2011; Latzman \& Masuda, 2013). For openness (Gloster, et al., 2011; Latzman \& Masuda, 2013) and agreeableness (Gámez, et al., 2011; Latzman \& Masuda, 2013), on the contrary, only small associations with psychological flexibility have been shown. Moreover, a meta-analysis (Steel, Schmidt, \& Schulz, 2008) showed that neuroticism is related positively to negative affect, but also negatively to life 
RUNNING HEAD: Personality, Flexibility and Well-Being

satisfaction/quality of life and positive affect, whereas extraversion and conscientiousness are related to more positive affect and life satisfaction/quality of life. For openness only a positive association with positive affect and no significant associations for agreeableness have been found.

The aim of the current study is to corroborate earlier findings (Steenhaut et al., 2019) of an indirect effect of personality on well-being through psychological flexibility in an independent sample, and to examine this further by also using a behavioural index of flexibility. Therefore, we extended our earlier research by developing an experimental approach focusing on a behavioral manifestation of psychological flexibility when making decisions. Using an ecologically relevant experimental setup, we operationalized the abovementioned ability to keep an open mindset to be able to flexibly choose the option that is adaptive to the situation. Given that, in order to make an adaptive choice, it is important to have balanced attention for both negative and positive information, we developed a task in which people can make decisions based on their interest for positive and negative information.

Theoretically, a positivity bias - thus focusing more on positive information - has often been linked to more well-being in aging research (e.g. Carstensen, Isaacowitz, \& Charles, 1999). However, Labouvie-Vief (2003) argued that always showing a positivity bias is detrimental for emotional development. It would reduce cognitive-affective complexity, and decrease the ability to tolerate negative emotions (e.g. important in grief) and to be empathic towards others. Deploying attention to both positive and negative aspects of a situation has been considered to be important for emotion regulation and to influence subjective well-being (Gross \& Thompson, 2007). Indeed, when one would always look at the bright side of situations in a rigid inflexible way, excitement and pleasure may lead to a false apprehension of reality, which may hamper dealing with difficulties to enhance well-being in the long term. Finding solutions or making decisions that are helpful often requires taking into account also negative information. As stated by Tamir and Gross (2011) the classic approach of emotion regulation is confined to investigating short-term consequences of emotions, ignoring the possibility that people may seek to regulate their emotions for reasons other than maximizing immediate pleasure. It has even been proposed that mania and addictions could also 
RUNNING HEAD: Personality, Flexibility and Well-Being

result from over-engagement with positive emotions (Hayes and Feldman, 2004). A lack of flexibility such as a negativity bias, is widely accepted to be detrimental for mental health and leads to less wellbeing or even depression (e.g. Sanchez, Vazquez, Marker, LeMoult, \& Joormann, 2013). However, there is less consensus about the consequences of being inflexible due to a positivity bias. Concerning age-related differences in choice flexibility, it has been questioned whether older adults would be equally flexible in showing attention towards both positive and negative information when necessary, given that an extensive amount of studies found that older adults show a positivity bias, compared to younger adults (for a review, see Reed, Chan, \& Mikels, 2014). Although this positive bias may

possibly explain older adults' improved well-being compared to younger adults (e.g. Carstensen, et al., 1999), it might not be adaptive (e.g. in decision making) to apply this biased viewing strategy at all times. Studies have been performed to examine whether this positivity bias still occurs in older adults compared to younger adults in situations in which taking both negative and positive information into account would be adaptive, such as in making (hypothetical) health decisions. In a study of Löckenhoff and Carstensen (2007), it could be demonstrated that older participants compared to younger adults did not show a positivity bias and thus a flexible approach, when they were urged to focus on facts and details of the received information (information-focused condition). However, in a free-viewing condition, they did show a positivity bias compared to younger adults. Likewise, Isaacowitz and Choi (2012) also observed a positivity effect in a free-viewing condition but, contrary to the study of Löckenhoff and Carstensen (2007), they also found age-differences in an informationfocused condition, showing that older adults looked less at both negative and informative zones. To conclude, age-related differences in flexibility in focusing in a balanced way to both positive and negative information remain unclear. Moreover, no studies have yet been performed investigating agerelated differences in the relationship between this form of behavioral flexibility and personality, and in the relationship between flexibility and well-being.

\section{Current Study}

Our first aim was to replicate earlier findings (Steenhaut et al., 2019) using questionnaires to measure psychological flexibility in independent samples of younger and older adults, so we used the same constructs. We included neuroticism, extraversion, and conscientiousness (the three Big Five 
RUNNING HEAD: Personality, Flexibility and Well-Being

personality traits with the most consistent and strongest relationships with both psychological flexibility and well-being in the literature, see above). Additionally, we assessed maladaptive traits, namely negative emotionality, low positive emotionality (or introversion), and disconstraint. To measure psychological flexibility, we used two different questionnaires because one is the most used one in previous research, namely the Acceptance and Action II questionnaire (AAQ-II; Bond, et al., 2011), whereas the "Flexibility Index Test" (FIT-60; Batink, Jansen, \& de Mey, 2012) is a broader measure of psychological flexibility yielding stronger results in our previous study. Subjective wellbeing consists of both affective and cognitive well-being. Affective well-being refers to the long-term emotional state of someone and is assessed by both positive and negative affect measures. Cognitive well-being has been defined as how people evaluate their life satisfaction (Diener, Suh, Lucas, \& Smith, 1999). For subjective well-being, two measures were applied as well. The Positive and Negative Schedule (PANAS; Watson, Clark, \& Tellegen, 1988) to assess the affective aspects and the World Health Organization Quality of Life - short version (WHOQOL-Bref; WHOQOL group, 1996) to measure general (cognitive) well-being. We expected neuroticism, negative emotionality, and low positive emotionality to have a negative influence on well-being through its negative influence on psychological flexibility, and extraversion and conscientiousness to have a positive influence on subjective well-being through their positive influence on psychological flexibility. Based on our former research, we also hypothesized to find stronger effects with the FIT-60 than with the AAQ-II. Finally, based on our former study, we did not expect age differences to occur (see Steenhaut et al., 2019).

Secondly, we extended our previous research by investigating indirect effect models with a behavioral measure of flexibility focusing on acquisition of negative and positive information when making choices. We created a choice task, analogue to the hypothetical health plan/doctor choice task of Löckenhoff and Carstensen (2007). We adapted this task to make it non-hypothetical and thus more personally relevant for both age groups (see methods). With ageing, people become more selective in using their resources in decision making and they put more effort in reviewing relevant and ignoring irrelevant information in decision making when personal relevance is higher (Hess, Germain, Rosenberg, Leclerc, \& Hodges, 2005). 
RUNNING HEAD: Personality, Flexibility and Well-Being

Based on prior findings with psychological flexibility (Steenhaut et al., 2019), we hypothesized that neuroticism, negative emotionality, and low positive emotionality would have a negative influence on subjective well-being, through a negative influence on flexibility, as measured with the behavioral task. Extraversion and conscientiousness would have a positive influence on subjective well-being through their positive influences on flexibility. Given the absence of research performed on age-related differences in flexibility in making choices based on personally relevant information, and their relations with personality and well-being, we considered it as an open question whether age-related differences would occur.

\section{Method}

\section{Participants}

We recruited 60 younger to mid-aged (25-50 years) and 60 older (65+) adults from a Dutchspeaking community sample with flyers, advertisement and social media, in recreational clubs and at educational centers for seniors. Before testing, we screened people over telephone. Individuals who reported uncorrected vision problems, known cognitive problems (i.e. dementia) or current psychiatric disorders (assessed with the MINI neuropsychiatric interview) were excluded from participating. Two older participants with invalid MMPI-2-RF profiles and one older participant who scored too low on the MMSE were excluded from all analyses. Analyses were performed with the remaining 60 younger adults $($ Mage $=30.88, S D=7.63$, range $=24-50)$ and 57 older adults $($ Mage $=71.68, S D=5.41$, range =65-91). Demographics and descriptive variables can be found in Table 1. Our samples were representative for the general Belgian population based on gender and marital status, but their educational level was higher than younger and older adults in the general population (Statistics Belgium, 2016). All participants were Caucasian, except for one, who had Belgian-Turkish roots. For analyses with flexibility as measured by the choice task, we additionally removed one older participant because of a technical problem with data storage, and one younger and one older adult due to extreme outliers which skewed the data (resp. skewness $=-3.83$ and -2.45 , kurtosis $=20.31$ and 7.80). Finally, for analyses with the WHOQOL we removed one older participant with too much missing data $(>20 \%)$. 
RUNNING HEAD: Personality, Flexibility and Well-Being

\section{Materials}

Mini International Neuropsychiatric Interview 5.0.0 (MINI). To screen participants for current psychiatric disorders, the MINI (Sheehan, et al., 1992; Dutch version: Overbeek, Schruers, \& Griez, 1999) was used. The MINI is a short screening interview with 20 yes/no questions, based on the Diagnostic and Statistical Manual Fourth Edition (DSM-IV; American Psychiatric Association, 1994) and the International Classification of Diseases (ICD-10; World Health Organization, 1992). If a question is answered with 'no', a current psychiatric diagnosis is excluded. If a question is answered with 'yes' further questions are asked to see whether a person should be excluded.

Mini-Mental State Examination (MMSE). Because we aimed at a cognitive healthy sample, the MMSE (Folstein, Folstein, \& McHugh, 1975; Dutch version: Kok \& Verhey, 2002) was administered in the older adult group to screen for cognitive impairment (e.g. mild dementia). Scores range from 0 to 30, with lower scores indicating more cognitive impairment. Older adults scoring lower than 27 were excluded, following the cut-off currently used in research (O'Bryant, et al., 2008).

Big Five Inventory (BFI). With the BFI (John \& Srivastava, 1999; Dutch version: Denissen, Geenen, Van Aken, Gosling, \& Potter, 2008) 44 statements have to be answered on a 5-point Likert scale ranging from 'totally disagree' to 'totally agree'. All scales were corrected for acquiescence (Rammstedt \& Farmer, 2013). The neuroticism, extraversion, and conscientiousness scales had good to acceptable internal consistencies (younger adults: resp. Cronbach's $\alpha=.84, .84$, and .83; older adults: .78, .85 , and .73$)$.

Minnesota Multiphasic Personality Inventory-2-Restructured Form (MMPI-2-RF). The MMPI-2-RF (Ben-Porath \& Tellegen, 2008; Dutch version: Van der Heijden et al., 2013) measures personality and psychopathology and consists of 338 'agree'/‘do not agree' statements. We used the following criteria: TRIN $<80$, VRIN $<80, \mathrm{~F}<110, \mathrm{Fp}<100, \mathrm{~L}<80$ and $\mathrm{K}<75$ (Van der Heijden, et al., 2013, pp. 36-50) to check whether a profile was valid. For this study the Personality Psychopathology Five revised scales (PSY-5-r; Harkness \& McNulty, 2007) were used. Internal consistencies ranged from good to acceptable for negative emotionality and low positive emotionality (younger adults: resp. Cronbach's $\alpha=.81, .78$; older adults: .78, .62). Cronbach's alpha's were 
RUNNING HEAD: Personality, Flexibility and Well-Being

acceptable for disconstraint in the younger adult group (.60), but low in the older adult group (.20) and was consequently excluded from the analyses.

Acceptance and Action Questionnaire-2 (AAQ-II). The AAQ-II (Bond, et al., 2011; Dutch version: Jacobs, Kleen, De Groot, \& A-Tjak, 2008) measures psychological flexibility and consists of seven statements that can be answered on a 7-point Likert scale, ranging from 'never true' to 'always true'. The AAQ-II has a good internal consistency in our younger (Cronbach's $\alpha=.86$ ) and an acceptable Cronbach's alpha in our older adult group (.71).

Flexibility Index Test [Flexibility Index Test] (FIT-60). The FIT-60 (Batink, et al., 2012) is a Dutch questionnaire to measure psychological flexibility. It consists of 60 items that need to be answered on a 7-point Likert scale, ranging from 'totally disagree' to 'totally agree'. Cronbach's alphas were good in both younger and older adults (both: .91).

Positive and Negative Schedule (PANAS). The PANAS (Watson, et al.,1988; Dutch version: Engelen, De Peuter, Victoir, Van Diest, \& Van den Bergh, 2006) assesses affective well-being, namely positive (PA) and negative affect (NA). It consists of 20 adjectives that need to be answered on a 5-point Likert scale, ranging from 'very little' to 'very much'. Both scales had high internal consistencies (resp. younger adults: .80 and .88; older adults: .90 and .86). Because we wanted to keep the analyses concise, we decided to combine the PA and NA into a global happiness score or affect balance scale (Diener, 2000) by calculating the ratio (PA/(PA + NA), analogue to Schwartz, Charles, Reynolds, Thase, Frank, \& Fasicka (2002).

World Health Organization Quality of Life - short version (WHOQOL-Bref). The WHOQOL (WHOQOL group, 1996; Dutch version: de Vries \& Van Heck, 1996) was used to measure general well-being and comprises 26 items that are measured on a 5-point Likert scale. The total WHOQOL score has good Cronbach's alpha's in both age groups (younger adults: .85; older adults: .92).

Choice flexibility task. A choice task was programmed in E-prime 2.0 Professional (Schneider, Eschman, \& Zuccolotto, 2002) and the stimuli were presented on a 17 inch computer screen. In order to make this task as realistic and relevant as possible, deception was used. Participants were told at the beginning of the experiment that they would have to complete a task in collaboration with a participant 
RUNNING HEAD: Personality, Flexibility and Well-Being

from the other age group at the end of the experiment. To create an optimal two-person team for the task, they would receive some information about other individuals, provided to us by two participants who allegedly collaborated with these persons in a previous, unrelated experiment. Based on this information they had to indicate their preference to collaborate or not to collaborate with this person later in the experiment. In reality there was no such collaboration task. The information we provided were thirty sentences used in the study of Heleven and Van Overwalle (2016). To prevent participants from making gender-biased choices, we adapted the sentences slightly to make them gender-neutral (see appendix A). Each trial started with a screen which had 'person [number]' written on top of it and contained two rows of five green (marked with ' $\mathrm{v}$ ' in case there were people with color-blindness) and five red (marked with ' $x$ ') numbered boxes which were presented in randomized order (see Figure 1).

Participants were told that the green boxes contained positive, and the red boxes contained negative sentences describing that person's characteristics. They could open each box by pressing the corresponding number on the keyboard. Once a new box was opened, the former one closed. They were free to choose how often they opened a box and how long they looked at a sentence. Once they felt they had gathered enough information, they had to press ' $b$ ' on the keyboard. Then a new screen appeared with following sentences: "Yes, I would rather like to collaborate with this person <press 'j'>” and "No, I would rather not like to collaborate with this person <press 'n'>”, to indicate their decision. Thereafter, a new trial started. In total there were three trials/persons. Participants were not aware on beforehand of the number of trials/persons, in order not to influence their decisions. During the choice flexibility task, the amount of times they opened a particular box, the time spent looking at the content of the boxes (the sentences), and their choices were logged. We then calculated a positivity index, similar to the one in Löckenhoff and Carstensen (2007): (total time spent looking at all positive sentences during all trials - total time spent looking at all negative sentences during all trials) / total time spent looking at all sentences during all trials. A score of zero indicates that participants took into account as much positive as negative information (flexible approach). The further the score deviates from zero, the more bias a person shows, with positive scores reflecting positivity biases and negative scores, negative biases. Given that we wanted to obtain a general measure of choice flexibility, we took the absolute value of the positivity index and then made all scores negative, so that higher scores 
RUNNING HEAD: Personality, Flexibility and Well-Being

$($ maximum $=0)$ reflect more flexibility and lower scores (below 0$)$ reflect less flexibility. We also mentioned the scores including the sign (+/-) when describing the variables and age differences in variables (see Table 1) to check whether the flexibility index is driven by a positive or a negative bias.

\section{Procedure}

This study was part of a larger older adult project approved by the ethical committee of the Faculty of psychological and educational sciences of Ghent University and the Vrije Universiteit Brussel. Participants first completed an informed consent and the personality and biographical questionnaires at home. Upon arrival at the laboratory, we again explained what would happen during the experiment and which tasks they would have to complete. First, they performed an eye-tracking task and emotional STROOP task to test other hypotheses unrelated to the aims of the current study, followed by the choice flexibility task. Then, an optional ten-minute break was provided, after which they filled in the remaining questionnaires for this study, followed by some questionnaires to test other hypotheses unrelated to the aims of the current study (BDI-II, STAI, EPQ-r Lie scale, MAAS, WBSI). The older adults also completed an MMSE interview. Finally, all participants were debriefed and were payed 20 euro's as expense compensation.

\section{Statistical Analyses}

Our database and syntax are available on Open Science Framework:

Data: https://mfr.osf.io/render?url=https\%3A\%2F\%2Fosf.io\%2Fexz73\%2Fdownload Syntax: https://mfr.osf.io/render?url=https\%3A\%2F\%2Fosf.io\%2Fdeprv\%2Fdownload All data appeared normally distributed (younger adults: skewness $=.20-1.40$ and kurtosis $=.15-$ 2.15; older adults: skewness $=.08-1.64$ and kurtosis $=.18-2.38$ ), so parametric tests were applied . We investigated whether personality (independent variable) has an indirect effect on subjective wellbeing (dependent variable) through a measure of flexibility (intermediate variable; see Figure 2). This research question was assessed by implementing the PROCESS macro with a stepwise approach using multiple regression analysis (Hayes, 2013). Model number four of this macro was used to perform simple indirect analyses. The a-path of Figure 2 represents the effect of personality on flexibility. Path $\mathrm{b}$ is the effect of flexibility on well-being. The total effect of personality on well-being, is represented 
RUNNING HEAD: Personality, Flexibility and Well-Being

through path c, which can be split up in the direct (path c') and the indirect (c - c') effect (see Table 3). Path c' is the direct effect of personality on well-being, controlled for flexibility and path $c-c^{\prime}$ is the indirect effect of personality running through flexibility. If path c' and $c-c^{\prime}$ are significant, personality has both direct and indirect influences on well-being through its effect on flexibility. However, if path $\mathrm{c}-\mathrm{c}^{\prime}$ is significant, but c' is not, it is indicative of a full indirect effect, which means that personality only has an influence on subjective well-being through its effect on flexibility.

As proposed by Preacher and Hayes (2008), an accelerated-bias-corrected bootstrapping method with 5000 estimates was used, to investigate whether the indirect effect was significantly different from zero. Confidence intervals for all effects were calculated. If this interval includes zero, effects are not significant.

Furthermore, we investigated whether age was a moderator on our indirect effect models. The same macro and steps were applied, except that this time model 59 of the macro was used with 'age group' (younger adults $=0$; older adults $=1$ ) as the moderator on the whole model (see Figure 2). For our research question we were interested in whether age has an effect on the indirect influence of personality on well-being through flexibility (path $c-c^{\prime}$ ), which could be interpreted from the index of the moderated indirect effect. This is a test of equality of the conditional indirect effects in the two groups. When the confidence interval includes zero, age has no significant effect, and the indirect effects are the same in both groups. In cases where the indirect effects differed between age groups, simple indirect effect analyses were performed in each age group separately.

\section{Results}

\section{Self-reported Psychological Flexibility}

Indirect effect analysis. Both neuroticism and negative emotionality had an indirect effect on well-being through psychological flexibility. When life satisfaction was used as the dependent variable we even found a full indirect effect (see Table 2). An indirect effect was also found with extraversion and low positive emotionality on the affect balance score, but only with the FIT-60 score and not with the AAQ-II score. Again, this effect fully ran through psychological flexibility for the relationship with life satisfaction. No significant indirect effects were found with conscientiousness (see Table 2). 
RUNNING HEAD: Personality, Flexibility and Well-Being

Moderated indirect effects analysis. Age was found to be a significant moderator on the indirect effect of neuroticism on life satisfaction through the FIT-60 score; on the indirect effect of extraversion on life satisfaction through the AAQ-II score; and on all analyses with conscientiousness (see Table 3).

Consequently, additional indirect effect analyses for these combinations were performed in both age groups separately (see Table 4). We found that in younger adults the effect of neuroticism on life satisfaction ran fully through psychological flexibility, as measured by the FIT-60, whereas in older adults this relationship was both indirect and direct. In older adults the relationship between extraversion and life satisfaction ran fully through the AAQ-II score, whereas there was no indirect effect in younger adults. Finally, the effect of conscientiousness on well-being ran fully through psychological flexibility, measured by both the AAQ-II and FIT-60, in the younger adults; and fully through the FIT-60, and partially through the AAQ-II in the older adults. The directions of the effects were, however, different in both age groups. In younger adults, conscientiousness had a negative influence on psychological flexibility, whereas in older adults it had a positive influence on psychological flexibility. Psychological flexibility had in both age groups a positive influence on wellbeing.

Several of the $a, b$, and c' paths were also significantly moderated by age, so we performed follow-up zero order correlations (see Table 5 for an overview of all correlations) and fisher $r$-to- $z$ transformations (http://vassarstats.net/rdiff.html) to see whether the relationships between these variables differed by age group. For the effect sizes, we used the following rule of thumb: a difference between two $z$-scores larger than .10 is a small effect size, a difference larger than .30 is a medium effect size and a difference larger than .50 is a large effect size (Cohen, 2009, pp. 109-139).

Conscientiousness was related significantly positive in younger adults and significantly negative in older adults to psychological flexibility (AAQ-II and FIT-60), and subjective well-being (both global happiness and life satisfaction). These correlations also differed significantly between both age groups with large effect sizes, resp.: $q=.91, p<.001 ; q=1.07, p<.001 ; q=.74, p<.001 ; q=.85, p<.001$. The relationship between neuroticism and life satisfaction appeared not to differ significantly between 
RUNNING HEAD: Personality, Flexibility and Well-Being

age groups $(q=.16, p=.313)$, nor did the relationship between flexibility and life satisfaction $(q=.02$, $p=.865)$.

\section{Choice Flexibility Task}

Indirect effect analysis. None of the indirect effects of personality on well-being through choice flexibility were significant (see Table 6). Personality traits did not have significant effects on choice rigidity (a-paths). Choice flexibility did not have significant effects on well-being (b-paths). The personality traits neuroticism and negative emotionality did have direct significant negative effects on global happiness and life satisfaction; extraversion and low positive emotionality had respectively significant positive and negative direct effects on global happiness, but not on life satisfaction. Finally, conscientiousness did not show a direct significant effect on neither measure of well-being (see Table 6).

Moderated indirect effects analysis. Age group did not have a moderating effect on the insignificant indirect effects of personality on well-being through choice flexibility (see Table 7). Regarding the $\mathrm{a}, \mathrm{b}$, and c' paths, only the c' path with conscientiousness influencing subjective wellbeing was moderated by age and is already described in the previous section.

\section{Discussion}

The current study had two aims. First, we wanted to corroborate findings with self-reported psychological flexibility in an independent sample of younger and older adults, testing whether the relationship between personality and subjective well-being would be indirectly related through psychological flexibility in both age groups. Secondly, we wanted to extend our results by operationalizing psychological flexibility, i.e. the ability to keep an open mindset to be able to flexibly choose the option that is adaptive to the situation, by development of a behavioural task were individuals have to make a choice based on both positive and negative information.

\section{Self-reported Psychological Flexibility}

As expected, and in line with the previous study (Steenhaut et al., 2019), the relationship between both neuroticism and negative emotionality and well-being ran partially through psychological flexibility. With life satisfaction this effect was three out of four times 
RUNNING HEAD: Personality, Flexibility and Well-Being

even a full mediator in younger adults and twice in older adults. This indicates that the effect of neuroticism and negative emotionality on life satisfaction (i.e. the cognitive component of subjective well-being) exerts its influence completely through psychological flexibility, whereas these personality traits have both direct and indirect effects on affective well-being (i.e. the affective component). We also found that the effect of extraversion and its maladaptive variant, low positive emotionality, on cognitive and affective well-being, also runs through psychological flexibility, but only when broadly measured by the FIT-60. Again, relationships with life satisfaction showed full indirect effects. In the previous study, relationships with low positive emotionality showed also only indirect effects as measured with the FIT-60 and not with the AAQ-II. A possible explanation is that aspects other than acceptation may play a more important role in the relationship between both extraversion and low positive emotionality, and subjective well-being. Finally, conscientiousness had a direct positive effect on well-being and an indirect positive effect on well-being through psychological flexibility in older adults, which is also in line with the previous study. Unexpectedly, in younger adults, conscientiousness had a negative effect on well-being through a negative effect on psychological flexibility, which is not in line with the previous study and also in opposite directions of relationships between conscientiousness and psychological flexibility (e.g. Latzman \& Masuda, 2013), and conscientiousness and wellbeing found in former studies (e.g. Steel, et al., 2008). An explanation for this unexpected result is that in our younger adult group, scores on conscientiousness were significantly related with higher negative emotionality, and lower positive emotionality (they were also positively related to higher neuroticism although not significant, see Table 5), whereas it consistently correlated negatively, although not always significantly, with these personality traits in our older sample (see Table 5) and in the samples of previous studies (Latzman \& Masuda, 2013; Steenhaut et al., 2019). The unexpected positive relationships between 
RUNNING HEAD: Personality, Flexibility and Well-Being

conscientiousness and the more 'negative' personality traits in our current younger adult sample remain difficult to explain. We therefore explored in more detail how conscientiousness was negatively related to psychological flexibility in younger adults, by including correlations between the BFI Conscientiousness facets 'order' and 'self-discipline', and 'psychological flexibility' measured by AAQ-2 and FIT-60 scales, including FIT-60 subscales (i.e. acceptance, cognitive defusion, being present, self as context, and committed action). Generally, correlations with the AAQ2 and FIT-60 scales were negative, yet with the exception of a positive correlation (.37) between the FIT-60 ‘committed action' scale and BFI ‘self-discipline' scale. Also, in older adults there was a positive correlation between the FIT-60 'committed action' and BFI 'self-discipline' scales (.67). All medium or large positive correlations of psychological flexibility scales in older adults were with the BFI scale 'self-discipline' and not with the BFI 'order' scale. Flexibility thus seems generally more related to reliability (i.e. self-discipline) than to organisation or inhibitory control (i.e. order), with the exception of 'committed action'. Reliability is one of the facets of Conscientiousness for which differential trajectories have been observed across the life-span (Mike, Harris, Roberts \& Jackson, 2015): increases in conscientiousness in later adulthood are driven by changes in reliability (besides conventionality), probably resulting in more positive correlations between psychological flexibility aspects in older adults and BFI 'self-discipline', whereas increases in conscientiousness earlier in life are more related to industriousness.

\section{Choice Flexibility}

Age differences in choice flexibility could be demonstrated (see Table 1). However, unlike in earlier studies (Isaacowitz \& Choi, 2012; Löckenhoff \& Carstensen, 2007), our older adult group did not show a positivity bias (see Table 1). Perhaps this is due to the high immediate relevance of the task in this study (i.e. having to participate with the chosen person later on). Importantly, also no agerelated differences were found in a bias to the negative information (see Table 1). We can conclude that the choice flexibility (giving equal attention to both positive and negative information) in the older age group was in general lower than in the younger age group but that this was not due to a general preference for either positive or negative stimuli in older adults. 
RUNNING HEAD: Personality, Flexibility and Well-Being

Unlike psychological flexibility and opposed to our expectations, the relationships between personality traits and subjective well-being did not run through choice flexibility as measured with our experimental behavioral task. Two paths of the mediation analyses were not significant: 1) flexibility or adaptation measured during the experimental task did not have a significant effect on general subjective well-being, and 2) the personality traits did not have a significant influence on choice flexibility. In order to strengthen our conclusions about the absence of effects with the choice flexibility task, we included Bayesian analyses (see Supplementary materials). These analyses show that there is indeed strong (negative values between 6 to 10 , on the $2 \log (\mathrm{BF})$-scale, see Kass \& Raftery, 1995) to very strong (negative values above 10) evidence that the data do not support mediation and moderated mediation for the models including choice flexibility (Bayes factors between -9.5 and -26$)$.

An explanation for not finding an effect of choice flexibility on well-being might be that this experimental task only measures momentary flexibility or adaptation skills of the participants. Although we made the choice task as ecologically valid as possible, it might be that our participants simply do not apply these strategies consistently over situations in daily life. If this would be the case, it would be logical that the amount of flexibility/adaptability measured in these situations does not have an influence on their general well-being, although it might have had an influence on temporary mood (which we did not assess). We implicitly assumed (see introduction) and in forming our hypotheses that if someone scores high on psychological flexibility, these individuals would also show more flexibility in their interest in emotional stimuli in order to make decisions. In both age groups, psychological flexibility did not show significant correlations with choice flexibility. So we might conclude that despite our efforts, our experimental task may not be an ecologically valid measure to assess how flexible people respond in general over daily situations, or that choice flexibility is not applied consistently over situations and therefore does not have a significant impact on general wellbeing.

Moreover, we also did not find a significant effect of personality traits on choice flexibility. It might be that choice flexibility as measured at one particular moment and context is not as stable as psychological flexibility as measured by the questionnaires. Indeed, the results may be method- 
RUNNING HEAD: Personality, Flexibility and Well-Being

induced. Significant influences of personality on psychological flexibility, and from psychological flexibility on well-being, may have been found because here we used self-report questionnaires with the instruction to answer as how you feel/react/behave in general.

\section{Limitations}

A first important limitation is that our data was cross-sectional, so causal directions of causality remain an open question. It is possible that our effects of personality on well-being through psychological flexibility might also be reciprocal, considering that effects of well-being on personality have also been found in longitudinal studies (e.g. Soto, 2015), although this effect was found to be weaker than the effect of personality on well-being. Consequently, longitudinal designs would be more informative to investigate causality.

Secondly, as already mentioned, the methods we used might have had an influence on our results with psychological flexibility (self-report questionnaires with the instruction to fill it in as 'in general') but not with choice flexibility (experiments in the moment). However, if choice flexibility would be stable over time and situations we would expect participants to act similarly in daily life and during the experiments. In future research choice flexibility could be measured over different points in time to yield a mean score over different situations/tasks to see whether these constructs are indeed unstable over different situations. Furthermore, it would be interesting to add a measure of state emotions (for example: the PANAS with the instruction: 'How do you feel at this moment?') to see whether choice flexibility would have a temporarily influence on mood or well-being.

\section{Conclusion}

In the first part of the study we largely succeeded to replicate results of a previous study, demonstrating that the relationship between personality traits and general well-being runs through psychological flexibility in both younger and older adults. Results of the second part of the study indicate that there are no indirect effects with an experimental task measuring flexibility in the relationships between personality and well-being. Nevertheless, these results may be indicative to focus on enhancing psychological flexibility to increase well-being. Validated treatments in both age groups, such as Acceptance and Commitment therapy (ACT; Hayes, Strosahl, \& Wilson, 1999) or mindfulness, already exist and could thus be easily implemented to improve psychological flexibility, 
RUNNING HEAD: Personality, Flexibility and Well-Being

and consequently well-being. Future research should further explore whether the used method has an influence on the results and whether choice or other forms of flexibility as operationalized by an experimental task would have influences on temporary mood states, and might be used as short-term strategy to enhance well-being. 
RUNNING HEAD: Personality, Flexibility and Well-Being

\section{Acknowledgement}

This research was part of the doctoral project of Dr. Priska Steenhaut, funded by The Research Foundation - Flanders (FWO; 11ZV517N); and the Psychopathology and Information Processing in Older Adults (PIPO) alliance grant [IV1: I/00125/01]. The funding source played no role in the study design, collection, analysis or interpretation of data, writing of the report nor in the decision to submit the article for publication.

We would like to thank all participants. We also thank Wannes De Kunst, Maroussia Meeus, and Lou Van Eynde (VUB master students in psychology) for their help in recruiting participants. Furthermore, we thank Bart Aben for his help in programming the choice task. Moreover, we want to thank Marie-Anne Vanderhasselt, Jens Allaert, and Tom Loeys for their advice with data analysis. Finally, we thank Maarten De Schryver for conducting the Bayesian analyses on the mediation and moderated mediation models.

\section{Declaration of Interest}

The authors declare that they have no conflict of interest. 
RUNNING HEAD: Personality, Flexibility and Well-Being

\section{References}

American Psychiatric Association (1994). Diagnostic and Statistical Manual of Mental Disorders, Fourth Edition. Washington, DC: American Psychiatric Association.

Batink, T., Jansen, G., \& Mey, H. R. A. de (2012). De Flexibiliteits Index Test (FIT-60): Een beknopte beschrijving. [The Flexibility Index Test (FIT-60): A concise description.] GZ-Psychologie, 5, $18-21$.

Ben-Porath, Y.S., \& Tellegen, A. (2008). MMPI-2-RF (Minnesota Multiphasic Personality Inventory2-Restructured Form) manual for administration, scoring, and interpretation. Minneapolis, MN: University of Minnesota Press.

Bond, F. W., Hayes, S. C., Baer, R. A., Carpenter, K. C., Guenole, N., Orcutt, H. K., Waltz, T., \& Zettle, R. D. (2011). Preliminary psychometric properties of the Acceptance and Action Questionnaire-II: A revised measure of psychological flexibility and acceptance. Behavior Therapy, 42, 676-688.

Bond, F. W., Lloyd, J., \& Guenole, N. (2013). The work-related acceptance and action questionnaire: Initial psychometric findings and their implications for measuring psychological flexibility in specific contexts. Journal of Occupational and Organizational Psychology, 86, 331-347.

Brinkborg, H., Michanek, J., Hesser, H., \& Berglund, G. (2011). Acceptance and commitment therapy for the treatment of stress among social workers: A randomized controlled trial. Behaviour Research and Therapy, 49, 389-398.

Carstensen, L.L., Isaacowitz, D.M., \& Charles, S.T. (1999). Taking time seriously - A theory of socioemotional selectivity. American Psychologist, 54, 165-181.

Cohen, J. (2009). Statistical power analysis for the behavioral sciences. ( $2^{\text {nd }}$ edition). New York, NY: Psychology Press.

Denissen, J.J.A., Geenen, R., van Aken, M.A.G., Gosling, S.D., \& Potter, J. (2008). Development and Validation of a Dutch Translation of the Big Five Inventory (BFI). Journal of Personality Assessment, 90, 152-157.

de Vries, J., \& Van Heck, G. L. (1996). De Nederlandse versie van de WHOQOL-Bref [The Dutch version of the WHOQOL-Bref]. Tilburg, NL: Tilburg University. 
RUNNING HEAD: Personality, Flexibility and Well-Being

Diener, E. (2000). Subjective Well-Being. The Science of Happiness and a Proposal for a National Index. American Psychologist, 55, 34-43.

Diener, E., Suh, E. M., Lucas, R. E., \& Smith, H. L. (1999). Subjective Well-Being: Three Decades of Progress. Psychological Bulletin, 125, 276-302.

Engelen, U., De Peuter, S., Victoir, A., Van Diest, I., \& Van den Bergh, O. (2006). Verdere validering van de Positive and Negative Affect Schedule (PANAS) en vergelijking van twee Nederlandstalige versies. [Further validation of the Positive and Negative Affect Schedule (PANAS) and comparison of two Dutch versions.] Gedrag en gezondheid, 34, 61-70.

Folstein, M.F., Folstein, S.E., \& McHugh, P.R. (1975). Mini-Mental state: A practical method for grading the cognitive state of patients for the clinician. Journal of Psychiatric Research, 12, 189-198.

Gámez, W., Chmielewski, M., Kotov, R., Ruggero, C., \& Watson, D. (2011). Development of a Measure of Experiential Avoidance: The Multidimensional Experiential Avoidance Questionnaire. Psychological Assessment, 23, 692-713.

Gloster, A. T., Klotsche, J., Chaker, S., Hummel, K. V., \& Hoyer, J. (2011). Assessing Psychological Flexibility: What Does It Add Above and Beyond Existing Constructs? Psychological Assessment, 23, 970-982.

Gross, J.J., \& Thompson, R.A. (2007). Emotion Regulation: Conceptual foundations. In J.J. Gross (Ed.), Handbook of emotion regulation. (pp. 3-24) New York: Guilford Press.

Gutiérrez, J. L. G., Jiménez, B. M., Hernández, E. G., \& Puente, C. P. (2005). Personality and subjective well-being: big five correlates and demographic variables. Personality and Individual Differences, 38, 1561-1569.

Harkness, A.R., \& McNulty, J.L. (2007). Restructured versions of the MMPI-2 Personality Psychopathology Five (PSY-5) scales. Paper presented at the annual meeting of the American Psychological Association, San Francisco.

Harris, M. A., Brett, C. E., Starr, J. M., Deary, I. J., \& Johnson, W. (2016). Personality and Other Lifelong Influences on Older-Age Health and Wellbeing: Preliminary Findings in Two Scottish Samples. European Journal of Personality, 30, 438-455. 
RUNNING HEAD: Personality, Flexibility and Well-Being

Hayes, A. (2013). Introduction to mediation, moderation, and conditional process analysis. A Regression-Based Approach. New York, NY: Guilford Press.

Hayes, A. M., \& Feldman, G. (2004). Clarifying the construct of mindfulness in the context of emotion regulation and the process of change in therapy. Clinical Psychological Science and Practice 11, 255-262. doi: 10.1093/clipsy.bph080

Hayes, S. C., Luoma, J. B., Bond, F. W., Masuda, A., \& Lillis, J. (2006). Acceptance and Commitment Therapy: Model, process and outcomes. Behavriour Research and Therapy, 44, $1-25$.

Hayes, S. C., Strosahl, K., \& Wilson, K. G. (1999). Acceptance and Commitment Therapy: An experiential approach to behavior change. New York (NY): Guilford Press.

Heleven, E., \& Van Overwalle, F. (2016). The person within: memory codes for persons and traits using fMRI repetition suppression. Social Cognitive and Affective Neuroscience, 11, 159-171.

Hess, T. M, Germain, C. M., Rosenberg, D. C., Leclerc, C. M., Hodges, E. A. (2005). Aging-Related Selectivity and Susceptibility to Irrelevant Affective Information in the Construction of Attitudes. Aging, Neuropsychology, and Cognition, 12, 149-174.

Isaacowitz, D. M., \& Choi, YS. (2012). Looking, Feeling, and Doing: Are There Age Differences in Attention, Mood, and Behavioral Responses to Skin Cancer Information? Health Psychology, $31,650-659$.

Jacobs, N., Kleen, M., De Groot, F., \& A-Tjak, J. (2008). Het meten van experiëntiële vermijding. De Nederlandstalige versie van de Acceptance and Action Questionnaire-II (AAQ-II). [The measurement of experiential avoidance. The Dutch version of the Acceptance and Action Questionnaire-II (AAQ-II)]. Gedragstherapie, 41, 349-361.

John, O. P., \& Srivastava, S. (1999). The Big Five trait taxonomy: History, measurement, and theoretical perspectives. In L. A. Pervin \& O. P. John (Eds.), Handbook of personality: Theory and research (pp. 102-138). New York, NY: Guilford Press.

Kashdan, T. B., \& Rottenberg, J. (2010). Psychological Flexibility as a Fundamental Aspect of Health. Clin Psychol Rev., 30, 865-878. 
RUNNING HEAD: Personality, Flexibility and Well-Being

Kass. R. E., \& Raftery, A. E. (1995). Bayes factors. Journal of the American Statistical Association, 90(430), 773-79.

Kok, R., \& Verhey, F. (2002). Gestandaardiseerde versie van de Mini-Mental State Examination [Standardized version of the Mini-Mental State Examination] (Folstein et al., 1975). Altrecht, NL: GGZ.

Labouvie-Vief, G. (2003). Dynamic Integration: Affect, Cognition, and the Self in Adulthood. Current Directions in Psychological Science, 12, 201-206.

Latzman, R. D., \& Masuda, A. (2013). Examining mindfulness and psychological inflexibility within the framework of Big Five personality. Personality and Individual Differences, 55, 129-134.

Löckenhoff, C. E., \& Carstensen, L. L. (2007). Aging, Emotion, and Health-Related Decision Strategies: Motivational Manipulations Can Reduce Age Differences. Psychology and Aging, 22, 134-146.

Mike, A., Harris, K., Roberts, B. W., \& Jackson, J.J. (2015). Conscientiousness. In J. D. Wright (Ed.)., International Encyclopedia of the Social and Behavioral Sciences (2nd ed.), pp. 658-665. USA: Elsevier.

O’Bryant, S. E., Humphreys, J. D., Smith, G. E., Ivnik, R. J., Graff-Radford, N. R., Petersen, R. C., \& Lucas, J. A. (2008). Detecting Dementia with the Mini-Mental State Examination (MMSE) in Highly Educated Individuals. Archives of Neurology, 65, 963-967.

Overbeek, T., Schruers, K., \& Griez, E. (1999). Mini International Neuropsychiatric Interview. Maastricht, NL: University of Maastricht.

Preacher, K. J., \& Hayes, A. F. (2008). Asymptotic and resampling strategies for assessing and comparing indirect effects in multiple mediator models. Behavior Research Methods, 40, 879891.

Rammstedt, B., \& Farmer, R.F. (2013). The Impact of Acquiescence on the Evaluation of Personality Structure. Psychological Assessment, 25, 1137-1145.

Reed, A.E., Chan, L., \& Mikels, J.A. (2014). Meta-Analysis of the Age-Related Positivity Effect: Age Differences in Preferences for Positive over Negative Information. Psychology and Aging, 29, $1-15$. 
RUNNING HEAD: Personality, Flexibility and Well-Being

Sanchez, A., Vazquez, C., Marker, C., LeMoult, J., \& Joormann, J. (2013). Attentional Disengagement Predicts Stress Recovery in Depression: An Eye-Tracking Study. Journal of Abnormal Psychology, 122, 303-313.

Scott, W., Daly, A., Yu, L., \& McCracken, L. M. (2017). Treatment of Chronic Pain for Adults 65 and Over: Analyses of Outcomes and Changes in Psychological Flexibility Following Interdisciplinary Acceptance and Commitment Therapy (ACT). Pain Medicine, 18, 252-264.

Schneider, W., Eschman, A., \& Zuccolotto, A. (2002). E-prime reference guide. Pittsburgh, PA: Psychology Software Tools.

Schwartz, R. M., Reynolds, C. F. III, Thase, M. E., Frank, E., \& Fasiczka, A. L. (2002). Optimal and Normal Affect Balance in Psychotherapy of Major Depression: Evaluation of the Balanced States of Mind Model. Behavioral and Cognitive Psychotherapy, 30, 439-450.

Sheehan, D. V., Lecrubier, Y., Sheehan, K. H., Amorim, P., Janavs, J., Weiller, E., Hergueta, T., Baker, R., \& Dunbar, G. C. (1998). The Mini-International Neuropsychiatric Interview (M.I.N.I.): the development and validation of a structured diagnostic psychiatric interview for DSM-IV and ICD-10. Journal of Clinical Psychiatry, 59, 22-33.

Soto, C. J. (2015). Is Happiness Good for Your Personality? Concurrent and Prospective Relations of the Big Five With Subjective Well-Being. Journal of Personality, 83, 45-55.

Statistics Belgium (2016). Statbel: België in cijfers. Retrieved from: https://bestat.statbel.fgov.be/bestat/crosstable.xhtml?view=1b9e219b-0387-4a70-880adc5eccaa244c

Steel, P., Schmidt, J., \& Shulz, J. (2008). Refining the Relationship Between Personality and Subjective Well-Being. Psychological Bulletin, 134, 138-161.

Steenhaut, P., Rossi, G., Demeyer, I., \& De Raedt, R. (2019). How is personality related to well-being in older and younger adults? The role of psychological flexibility. International Psychogeriatrics, 31, 1355-1365.

Tamir, M., \& Gross, J. J. (2011). Beyond pleasure and pain? Emotion regulation and positive psychology, pp. 89-100, in Designing Positive Psychology: Taking Stock and Moving 
RUNNING HEAD: Personality, Flexibility and Well-Being

Forward, eds K. M. Sheldon, T. B. Kashdan, and M. F. Steger. New York: Oxford University Press.

Van der Heijden, P., Derksen, J., Egger, J., Rossi, G., Laheij, M., \& Bögels, T. (2013). MMPI- 2-RF. Handleiding voor afname, scoring en interpretatie. [MMPI-2-RF. Manual for assesment, scoring and interpretation.] Nijmegen, NL: Pen Tests.

Watson, D., Clark, L. A., \& Tellegen, A. (1988). Development and validation of brief measures of positive and negative affect: The PANAS scales. Journal of Personality and Social Psychology, 54, 1063-1070.

WHOQOL group (1996). WHOQOL-Bref. Geneva, CH: WHO.

World Health Organization (1992). International Classification of Diseases, Tenth Revision. Geneva, Switzerland: World Health Organization. 
RUNNING HEAD: Personality, Flexibility and Well-Being

\section{Appendix A}

\section{Persoon 1: [Person 1]}

Wenst de anderen veel success. [Wishes the others good luck]

Doet minder werk dan de andere. [Does less work than the other]

Gaf ons de verkeerde instructies. [Gave us the wrong instructions]

Probeert mee naar een uitkomst te zoeken. [Helps trying to find a solution]

Neemt koekjes mee voor ons. [Brings us cookies]

Rolt met de ogen. [Rolls with the eyes]

Excuseert zich voor eigen vergissing. [Apologizes for own mistake]

Geeft de ander opbouwende feedback. [Gives the other constructive feedback]

Kijkt de ander raar aan. [Looks at the other in a weird way]

Verzendt een mail met typfouten. [Sends an e-mail with typos]

Persoon 2: [Person 2]

Verheft de stem tegen de andere. [Raises voice towards the other]

Geeft eigen foutje meteen toe. [Admits own mistake immediately]

Durft de eigen mening niet te geven. [Doesn't dare to give own opinion]

Geeft een compliment. [Gives a compliment]

Luistert niet goed naar de uitleg. [Does not pay attention to the instructions]

Zoekt mee naar een oplossing. [Searches for a solution]

Wendt de blik vaak af. [Often gazes away]

Regelt de takenverdeling. [Arranges the distribution of tasks]

Begint zuchtend aan de opdracht. [Starts the assignment while sighing]

Geeft de ander advies. [Gives the other advice]

Persoon 3: [Person 3]

Kijkt de ander een beetje neerbuigend aan. [Looks at the other in a condescending way]

Vertelt de andere wat nonsens. [Tells the other some nonsense]

Doet de andere een plezier. [Does the other a favor]

Houdt de deur voor iemand open. [Holds the door for someone]

Zoekt snel een uitvlucht. [Quickly searches for an excuse]

Bedenkt nieuwe ideeën. [Thinks of new ideas]

Maakt de berekeningen precies. [Performs the calculations exactly]

Let niet op tijdens het gesprek. [Doesn't pay attention during the conversation] 
RUNNING HEAD: Personality, Flexibility and Well-Being

Noteert alles grondig. [Makes precise notes]

Uit het ongenoegen over de ander. [Expresses discontentment about the other] 
RUNNING HEAD: Personality, Flexibility and Well-Being

Table 1.

Demographics and descriptive variables per age group

\begin{tabular}{|c|c|c|c|c|c|}
\hline & Younger adults & Older adults & $X^{2}$ & $p$ & \\
\hline \multicolumn{6}{|l|}{ Marital status } \\
\hline \multirow[t]{2}{*}{ Married/living together } & $43.33 \%$ & $64.91 \%$ & & & \\
\hline & $56.67 \%$ & $35.09 \%$ & 5.48 & .019 & \\
\hline \multicolumn{6}{|l|}{ Single/divorced/widow(er) } \\
\hline \multicolumn{6}{|l|}{ Education level } \\
\hline Primary school & $1.67 \%$ & $8.77 \%$ & & & \\
\hline Secondary school & $15.00 \%$ & $19.30 \%$ & & & \\
\hline Higher education & $83.33 \%$ & $71.93 \%$ & 3.68 & .159 & \\
\hline \multicolumn{6}{|l|}{ Gender } \\
\hline Male & $50 \%$ & $47.37 \%$ & & & \\
\hline Female & $50 \%$ & $52.63 \%$ & .08 & .776 & \\
\hline Personality traits & $\begin{array}{l}\text { YA mean } \\
\text { score/(SD) }\end{array}$ & $\begin{array}{l}\text { OA mean } \\
\text { score/(SD) }\end{array}$ & $t$-value (df) & $p$ & Cohen's $d$ \\
\hline Neuroticism & $-.22(.63)$ & $-.43(.58)$ & $1.84(115)$ & .068 & .35 \\
\hline Extraversion & $.19(.65)$ & $.39(.64)$ & $-1.62(115)$ & .107 & .31 \\
\hline Conscientiousness & $.49(.55)$ & $.55(.47)$ & $-.66(115)$ & .512 & .12 \\
\hline Negative emotionality & $6.15(4.05)$ & $5.67(3.68)$ & $.67(115)$ & .501 & .12 \\
\hline Low positive emotionality & $8.48(3.87)$ & $8.70(3.02)$ & $-.34(110.94)$ & .734 & .06 \\
\hline \multicolumn{6}{|l|}{ Flexibility measures } \\
\hline$\overline{\text { AAQ-II }}$ & $38.97(5.88)$ & $39.39(4.91)$ & $-.42(115)$ & .676 & .08 \\
\hline FIT-60 & $240.35(31.84)$ & $242.88(30.68)$ & $-.44(115)$ & .663 & .08 \\
\hline Choice flexibility & $-.10(.10)$ & $-.15(.14)$ & $2.43(112)$ & .017 & .41 \\
\hline $\begin{array}{l}\text { Positivity index choice } \\
\text { flexibility }\end{array}$ & $-.06(.13)$ & $-.03(.25)$ & $-.69(80.78)$ & .495 & .15 \\
\hline \multicolumn{6}{|l|}{ Well-Being measures } \\
\hline AB (Affect Balance PANAS) & $.66(.08)$ & $.68(.08)$ & $-.91(115)$ & .367 & .25 \\
\hline W (WHOQOL-Bref.) & $104.88(9.00)$ & $105.73(11.67)$ & $-.44(114)$ & .660 & .08 \\
\hline
\end{tabular}


RUNNING HEAD: Personality, Flexibility and Well-Being

Table 2

Indirect effects with psychological flexibility in total group.

\begin{tabular}{|c|c|c|c|c|c|c|c|c|}
\hline & \multicolumn{4}{|l|}{ Path a } & \multicolumn{4}{|l|}{ Path b } \\
\hline & $\beta$ & $t$ & $p$ & CI & $\beta$ & $t$ & $p$ & CI \\
\hline $\mathrm{N}-\mathrm{A}-\mathrm{AB}$ & -4.31 & -5.14 & $<.001$ & {$[-5.97 ;-2.65]$} & .004 & 4.26 & $<.001$ & {$[.002 ; .006]$} \\
\hline $\mathrm{N}-\mathrm{A}-\mathrm{W}$ & -4.28 & -5.07 & $<.001$ & {$[-5.95 ;-2.61]$} & .91 & 4.63 & $<.001$ & {$[.52 ; 1.30]$} \\
\hline $\mathrm{N}-\mathrm{F}-\mathrm{AB}$ & -32.55 & -8.85 & $<.001$ & {$[-39.84 ;-25.27]$} & .001 & 5.33 & $<.001$ & {$[.001 ; .002]$} \\
\hline $\mathrm{N}-\mathrm{F}-\mathrm{W}$ & -32.78 & -8.91 & $<.001$ & {$[-40.07 ;-25.49]$} & .21 & 4.42 & $<.001$ & {$[.11 ; .30]$} \\
\hline$E-A-A B$ & .92 & 1.03 & .305 & {$[-.85 ; 2.69]$} & .01 & 7.16 & $<.001$ & {$[.006 ; .01]$} \\
\hline$E-A-W$ & .82 & .90 & .370 & {$[-.98 ; 2.61]$} & 1.05 & 6.29 & $<.001$ & {$[.72 ; 1.38]$} \\
\hline$E-F-A B$ & 15.03 & 3.51 & $<.001$ & {$[6.55 ; 23.51]$} & .002 & 8.08 & $<.001$ & {$[.001 ; .002]$} \\
\hline$E-F-W$ & 15.82 & 3.69 & $<.001$ & {$[7.32 ; 24.31]$} & .21 & 6.87 & $<.001$ & {$[.15 ; .28]$} \\
\hline$C-A-A B$ & -.70 & -.61 & .546 & {$[-2.99 ; 1.59]$} & .01 & 6.73 & $<.001$ & {$[.006 ; .01]$} \\
\hline $\mathrm{C}-\mathrm{A}-\mathrm{W}$ & -.79 & -.68 & .495 & {$[-3.09 ; 1.50]$} & 1.08 & 6.18 & $<.001$ & {$[.74 ; 1.43]$} \\
\hline $\mathrm{C}-\mathrm{F}-\mathrm{AB}$ & 4.30 & .60 & .547 & {$[-9.78 ; 18.38]$} & .002 & 8.43 & $<.001$ & {$[.0015 ; .002]$} \\
\hline $\mathrm{C}-\mathrm{F}-\mathrm{W}$ & 4.69 & .66 & .513 & {$[-9.45 ; 18.83]$} & .20 & 6.70 & $<.001$ & {$[.14 ; .27]$} \\
\hline $\mathrm{NE}-\mathrm{A}-\mathrm{AB}$ & -.70 & -4.72 & $<.001$ & {$[-.99 ;-.40]$} & .004 & 4.25 & $<.001$ & {$[.002 ; .006]$} \\
\hline $\mathrm{NE}-\mathrm{A}-\mathrm{W}$ & -.69 & -4.68 & $<.001$ & {$[-.99 ;-.40]$} & .84 & 4.28 & $<.001$ & {$[.45 ; 1.22]$} \\
\hline $\mathrm{NE}-\mathrm{F}-\mathrm{AB}$ & -5.40 & -9.44 & $<.001$ & {$[-6.53 ;-4.27]$} & .001 & 5.42 & $<.001$ & {$[.001 ; .002]$} \\
\hline $\mathrm{NE}-\mathrm{F}-\mathrm{W}$ & -5.42 & -9.51 & $<.001$ & {$[-6.55 ;-4.29]$} & .19 & 5.02 & $<.001$ & {$[.11 ; .26]$} \\
\hline $1 \mathrm{P}-\mathrm{A}-\mathrm{AB}$ & -.26 & -1.56 & .122 & {$[-.59 ; .07]$} & .01 & 7.12 & $<.001$ & {$[.006 ; .01]$} \\
\hline $\mathrm{IP}-\mathrm{A}-\mathrm{W}$ & -.26 & -1.58 & .118 & {$[-.60 ; .07]$} & 1.03 & 6.06 & $<.001$ & {$[.69 ; 1.37]$} \\
\hline $\mathrm{IP}-\mathrm{F}-\mathrm{AB}$ & -2.74 & -2.94 & .004 & {$[-4.58 ;-.89]$} & .002 & 8.21 & $<.001$ & {$[.001 ; .002]$} \\
\hline \multirow[t]{3}{*}{$\mathrm{P}-\mathrm{F}-\mathrm{W}$} & -2.73 & -2.93 & .004 & {$[-4.57 ;-.88]$} & .20 & 6.92 & $<.001$ & {$[.15 ; .26]$} \\
\hline & \multicolumn{4}{|l|}{ Path c' } & \multicolumn{4}{|c|}{ Path $c-c^{\prime}$} \\
\hline & $\beta$ & $t$ & $p$ & $\mathrm{CI}$ & Effect & $\mathrm{CI}$ & & \\
\hline $\mathrm{N}-\mathrm{A}-\mathrm{AB}$ & -.08 & -10.24 & $<.001$ & {$[-.10 ;-.07]$} & -.02 & {$[-.0$} & $8 ;-.008]$ & \\
\hline $\mathrm{N}-\mathrm{A}-\mathrm{W}$ & -2.84 & -1.75 & .083 & {$[-6.05 ; .38]$} & -3.89 & {$[-6$.} & $7 ;-2.11]$ & \\
\hline $\mathrm{N}-\mathrm{F}-\mathrm{AB}$ & -.06 & -6.53 & $<.001$ & {$[-.08 ;-.04]$} & -.04 & {$[-.0$} & $-.02]$ & \\
\hline $\mathrm{N}-\mathrm{F}-\mathrm{W}$ & .02 & .01 & .991 & {$[-4.25 ; 4.29]$} & -6.75 & {$[-10$} & $38 ;-3.96]$ & \\
\hline$E-A-A B$ & .04 & 5.03 & $<.001$ & {$[.02 ; .05]$} & .01 & {$[-.0$} & $5 ; .02]$ & \\
\hline$E-A-W$ & 1.34 & 1.17 & .246 & {$[-.93 ; 3.60]$} & .86 & {$[-.9$} & $3.02]$ & \\
\hline$E-F-A B$ & .02 & 2.54 & .013 & {$[.004 ; .03]$} & .03 & {$[.01$} & $.05]$ & \\
\hline$E-F-W$ & -1.19 & -.94 & .349 & {$[-3.69 ; 1.31]$} & 3.38 & {$[1.4$} & ; 5.87] & \\
\hline$C-A-A B$ & .01 & 1.10 & .274 & {$[-.01 ; .04]$} & -.01 & {$[-.0$} & $.01]$ & \\
\hline $\mathrm{C}-\mathrm{A}-\mathrm{W}$ & 2.53 & 1.54 & .127 & {$[-.73 ; 5.78]$} & -.86 & {$[-3$.} & $7 ; 1.21]$ & \\
\hline $\mathrm{C}-\mathrm{F}-\mathrm{AB}$ & -.001 & -.10 & .920 & {$[-.02 ; .02]$} & .01 & {$[-.0$} & $.03]$ & \\
\hline $\mathrm{C}-\mathrm{F}-\mathrm{W}$ & .71 & .44 & .658 & {$[-2.45 ; 3.87]$} & .96 & {$[-1$.} & ; 3.62] & \\
\hline $\mathrm{NE}-\mathrm{A}-\mathrm{AB}$ & -.01 & -7.51 & $<.001$ & {$[-.01 ;-.009]$} & -.003 & {$[-.0$} & $5 ;-.002]$ & \\
\hline $\mathrm{NE}-\mathrm{A}-\mathrm{W}$ & -.64 & -2.40 & .018 & {$[-1.17 ;-.11]$} & -.58 & {$[-1$.} & $1 ;-.28]$ & \\
\hline $\mathrm{NE}-\mathrm{F}-\mathrm{AB}$ & -.01 & -4.66 & $<.001$ & {$[-.01 ;-.004]$} & -.01 & {$[-.0$} & $-.005]$ & \\
\hline $\mathrm{NE}-\mathrm{F}-\mathrm{W}$ & -.19 & -.67 & .502 & {$[-.76 ; .37]$} & -1.03 & & $2 ;-.64]$ & \\
\hline $1 \mathrm{P}-\mathrm{A}-\mathrm{AB}$ & -.01 & -3.72 & $<.001$ & {$[-.01 ;-.003]$} & -.002 & & $.0003]$ & \\
\hline $1 \mathrm{P}-\mathrm{A}-\mathrm{W}$ & -.31 & -1.12 & .267 & {$[-.87 ; .24]$} & -.27 & & $.02]$ & \\
\hline $\mathrm{IP}-\mathrm{F}-\mathrm{AB}$ & -.003 & -2.33 & .021 & {$[-.01 ;-.001]$} & -.01 & & ; -.002] & \\
\hline $\mathrm{IP}-\mathrm{F}-\mathrm{W}$ & -.03 & -.10 & .921 & {$[-.54 ; .49]$} & -.56 & & $2 ; .19]$ & \\
\hline
\end{tabular}

Note. Bold $=$ Mediation, Italic $=$ Full Mediation. $\mathrm{CI}=95 \%$ confidence interval, $\mathrm{N}=$ neuroticism, $\mathrm{E}=$ extraversion, $\mathrm{C}=$ conscientiousness, $\mathrm{NE}=$ negative emotionality, $\mathrm{IP}=$ low positive emotionality, $\mathrm{A}=$ score on the AAQ-II, $\mathrm{F}=$ score on the FIT-60, AB = Affect Balance PANAS, W = WHOQOL-Bref. Path a = effect personality on flexibility. Path $b=$ effect flexibility on well-being. Path $c^{\prime}=$ direct effect personality on well-being. Path $c-c^{\prime}=$ indirect effect of personality on well-being. 
RUNNING HEAD: Personality, Flexibility and Well-Being

Table 3

Interactions of age on the different steps in the indirect effect analyses with psychological flexibility.

\begin{tabular}{|c|c|c|c|c|c|c|c|c|}
\hline & \multicolumn{4}{|l|}{ Path a } & \multicolumn{4}{|l|}{ Path b } \\
\hline & $\beta$ & $t$ & $p$ & $\mathrm{CI}$ & $\beta$ & $t$ & $p$ & $\mathrm{CI}$ \\
\hline $\mathrm{N}-\mathrm{A}-\mathrm{AB}$ & -.26 & -.15 & .882 & {$[-3.73 ; 3.21]$} & .0003 & .13 & .894 & {$[-.004 ; .005]$} \\
\hline $\mathrm{N}-\mathrm{A}-\mathrm{W}$ & -.16 & -.09 & .927 & {$[-3.64 ; 3.31]$} & .63 & 1.42 & .159 & {$[-.25 ; 1.52]$} \\
\hline $\mathrm{N}-\mathrm{F}-\mathrm{AB}$ & -10.23 & -1.37 & .173 & {$[-25.03 ; 4.57]$} & .0004 & 1.00 & .321 & {$[-.0004 ; .001]$} \\
\hline $\mathrm{N}-\mathrm{F}-\mathrm{W}$ & -11.07 & -1.48 & .143 & {$[-25.94 ; 3.80]$} & .20 & 2.41 & .18 & {$[.04 ; .36]$} \\
\hline$E-A-A B$ & 3.16 & 1.79 & .076 & {$[-.34 ; 6.67]$} & -.0004 & -.14 & .888 & {$[-.01 ; .005]$} \\
\hline$E-A-W$ & 2.98 & 1.67 & .097 & {$[-.55 ; 6.52]$} & .45 & 1.15 & .252 & {$[-.33 ; 1.24]$} \\
\hline$E-F-A B$ & 9.46 & 1.07 & .287 & {$[-8.06 ; 26.97]$} & .0002 & .48 & .634 & {$[-.001 ; .001]$} \\
\hline$E-F-W$ & 11.66 & 1.34 & .184 & {$[-5.56 ; 28.87]$} & .09 & 1.34 & .182 & {$[-.04 ; .21]$} \\
\hline $\mathrm{C}-\mathrm{A}-\mathrm{AB}$ & 7.62 & 3.72 & $<.001$ & {$[3.56 ; 11.67]$} & .0004 & .16 & .874 & {$[-.01 ; .01]$} \\
\hline $\mathrm{C}-\mathrm{A}-\mathrm{W}$ & 7.44 & 3.62 & $<.001$ & {$[3.37 ; 11.51]$} & .31 & .75 & .457 & {$[-.52 ; 1.14]$} \\
\hline $\mathrm{C}-\mathrm{F}-\mathrm{AB}$ & 50.13 & 4.53 & $<.001$ & {$[28.20 ; 72.06]$} & .0003 & .77 & .443 & {$[-.001 ; .001]$} \\
\hline $\mathrm{C}-\mathrm{F}-\mathrm{W}$ & 51.63 & 4.69 & $<.001$ & {$[29.80 ; 73.45]$} & .05 & .85 & .399 & {$[-.07 ; .18]$} \\
\hline $\mathrm{NE}-\mathrm{A}-\mathrm{AB}$ & .33 & 1.15 & .252 & {$[-.24 ; .90]$} & .002 & 1.13 & .261 & {$[-.002 ; .007]$} \\
\hline$N E-A-W$ & .34 & 1.18 & .239 & {$[-.23 ; .91]$} & .69 & 1.72 & .089 & {$[-.11 ; 1.49]$} \\
\hline $\mathrm{NE}-\mathrm{F}-\mathrm{AB}$ & .48 & .41 & .679 & {$[-1.81 ; 2.76]$} & .0004 & .84 & .405 & {$[-.001 ; .002]$} \\
\hline$N E-F-W$ & .42 & .37 & .714 & {$[-1.85 ; 2.70]$} & .15 & 2.01 & .047 & {$[.002 ; .30]$} \\
\hline $1 \mathrm{P}-\mathrm{A}-\mathrm{AB}$ & .18 & .53 & .598 & {$[-.49 ; .85]$} & .002 & .95 & .344 & {$[-.003 ; .01]$} \\
\hline $\mathrm{IP}-\mathrm{A}-\mathrm{W}$ & .17 & .50 & .615 & {$[-.50 ; .84]$} & .53 & 1.47 & .144 & {$[-.18 ; 1.25]$} \\
\hline $1 \mathrm{P}-\mathrm{F}-\mathrm{AB}$ & 1.43 & .66 & .508 & {$[-2.83 ; 5.69]$} & .001 & .98 & .329 & {$[-.001 ; .001]$} \\
\hline \multirow[t]{3}{*}{$\mathrm{IP}-\mathrm{F}-\mathrm{W}$} & 1.46 & .68 & .499 & {$[-2.80 ; 5.72]$} & .08 & 1.27 & .206 & {$[-.04 ; .20]$} \\
\hline & \multicolumn{4}{|l|}{ Path c' } & \multicolumn{4}{|c|}{$\begin{array}{l}\text { Index of moderated mediation: } \\
\text { path } c-c^{\prime}\end{array}$} \\
\hline & $\beta$ & $t$ & $p$ & $\mathrm{CI}$ & Index & CI & & \\
\hline $\mathrm{N}-\mathrm{A}-\mathrm{AB}$ & .0004 & .02 & .984 & {$[-.04 ; .04]$} & -.002 & {$[-.02$} & 02] & \\
\hline $\mathrm{N}-\mathrm{A}-\mathrm{W}$ & 3.41 & .93 & .356 & {$[-3.87 ; 10.68]$} & -2.91 & {$[-7.8$} & $1.56]$ & \\
\hline $\mathrm{N}-\mathrm{F}-\mathrm{AB}$ & .03 & 1.29 & .200 & {$[-.01 ; .06]$} & -.03 & {$[-.06$} & $005]$ & \\
\hline $\mathrm{N}-\mathrm{F}-\mathrm{W}$ & 9.91 & 2.44 & .016 & {$[1.87 ; 17.95]$} & -9.42 & {$[-15]$.} & $;-3.58]$ & \\
\hline$E-A-A B$ & -.01 & -.35 & .726 & {$[-.04 ; .03]$} & .02 & {$[-.003$} & $.05]$ & \\
\hline$E-A-W$ & -1.11 & -.41 & .685 & {$[-6.54 ; 4.32]$} & 3.72 & {$[.37$} & 38] & \\
\hline$E-F-A B$ & -.002 & -.14 & .887 & {$[-.03 ; .03]$} & .02 & {$[-.02 ;$} & $05]$ & \\
\hline$E-F-W$ & -1.36 & -.49 & .626 & {$[-6.89 ; 4.16]$} & 3.97 & {$[-.40$} & .50 & \\
\hline $\mathrm{C}-\mathrm{A}-\mathrm{AB}$ & .04 & 1.71 & .090 & {$[-.01 ; .09]$} & .06 & {$[.03$} & & \\
\hline $\mathrm{C}-\mathrm{A}-\mathrm{W}$ & 7.67 & 2.07 & .040 & {$[.34 ; 14.99]$} & 7.31 & {$[3.21$} & [3.08] & \\
\hline $\mathrm{C}-\mathrm{F}-\mathrm{AB}$ & .001 & .04 & .969 & {$[-.04 ; .04]$} & .10 & {$[.06$} & & \\
\hline $\mathrm{C}-\mathrm{F}-\mathrm{W}$ & 4.56 & 1.43 & .157 & {$[-1.77 ; 10.90]$} & 10.42 & {$[6.25$} & [6.17] & \\
\hline $\mathrm{NE}-\mathrm{A}-\mathrm{AB}$ & -.001 & -.35 & .724 & {$[-.01 ; .01]$} & -.0001 & {$[-.00$} & $.004]$ & \\
\hline $\mathrm{NE}-\mathrm{A}-\mathrm{W}$ & .39 & .70 & .488 & {$[-.73 ; 1.52]$} & -.17 & {$[-.90$} & 53] & \\
\hline $\mathrm{NE}-\mathrm{F}-\mathrm{AB}$ & .001 & .14 & .889 & {$[-.01 ; .01]$} & .002 & [-.01; & $004]$ & \\
\hline$N E-F-W$ & .97 & 1.54 & .126 & {$[-.28 ; 2.22]$} & -.74 & {$[-1.6]$} & $.14]$ & \\
\hline $1 \mathrm{P}-\mathrm{A}-\mathrm{AB}$ & .003 & .74 & .461 & {$[-.005 ; .01]$} & .001 & {$[-.00$} & $.01]$ & \\
\hline $\mathrm{PP}-\mathrm{A}-\mathrm{W}$ & .27 & .39 & .697 & {$[-1.08 ; 1.61]$} & .06 & [-.64; & 88] & \\
\hline $1 \mathrm{P}-\mathrm{F}-\mathrm{AB}$ & .002 & .70 & .483 & {$[-.004 ; .01]$} & .002 & {$[-.01$; } & $01]$ & \\
\hline $1 \mathrm{P}-\mathrm{F}-\mathrm{W}$ & .22 & .37 & .715 & {$[-.96 ; 1.39]$} & .10 & {$[-.87$} & $.10]$ & \\
\hline
\end{tabular}


RUNNING HEAD: Personality, Flexibility and Well-Being

Table 4

Indirect effects in separate age groups

\begin{tabular}{|c|c|c|c|c|c|c|c|c|}
\hline \multicolumn{9}{|c|}{ Path b } \\
\hline & $\beta$ & $t$ & $p$ & $\mathrm{CI}$ & $\beta$ & $t$ & $p$ & $\mathrm{CI}$ \\
\hline $\mathrm{N}-\mathrm{F}-\mathrm{W}$ & -28.58 & -4.92 & $<.001$ & {$[-40.21 ;-16.96]$} & .14 & 2.54 & .014 & {$[.03 ; .25]$} \\
\hline$E-A-W$ & -.62 & -.39 & .695 & {$[-3.76 ; 2.52]$} & .89 & 3.63 & $<.001$ & {$[.40 ; 1.38]$} \\
\hline $\mathrm{C}-\mathrm{A}-\mathrm{AB}$ & -3.87 & -2.56 & .013 & {$[-6.90 ;-.84]$} & .01 & 4.30 & $<.001$ & {$[.004 ; .01]$} \\
\hline $\mathrm{C}-\mathrm{A}-\mathrm{W}$ & -3.87 & -2.56 & .013 & {$[-6.90 ;-.84]$} & .83 & 3.43 & .001 & {$[.35 ; 1.32]$} \\
\hline $\mathrm{C}-\mathrm{F}-\mathrm{AB}$ & -16.52 & -1.80 & .077 & {$[-34.88 ; 1.83]$} & .002 & 5.00 & $<.001$ & {$[.001 ; .003]$} \\
\hline \multirow[t]{3}{*}{$\mathrm{C}-\mathrm{F}-\mathrm{W}$} & -16.52 & -1.80 & .077 & {$[-34.88 ; 1.83]$} & .17 & 3.71 & $<.001$ & {$[.08 ; .25]$} \\
\hline & \multicolumn{4}{|c|}{ Path c' } & \multicolumn{4}{|c|}{ Path c - c' } \\
\hline & $\beta$ & $t$ & $p$ & $\mathrm{CI}$ & Effect & $\mathrm{CI}$ & & \\
\hline $\mathrm{N}-\mathrm{F}-\mathrm{W}$ & -3.02 & -1.21 & .231 & {$[-8.01 ; 1.97]$} & -4.01 & {$[-7.8$} & 1.53] & \\
\hline$E-A-W$ & 1.48 & .90 & .373 & {$[-1.82 ; 4.77]$} & -.55 & {$[-3.0$} & $.50]$ & \\
\hline $\mathrm{C}-\mathrm{A}-\mathrm{AB}$ & -.01 & -.35 & .729 & {$[-.04 ; .03]$} & -.03 & {$[-.07$} & & \\
\hline $\mathrm{C}-\mathrm{A}-\mathrm{W}$ & -1.27 & -.56 & .580 & {$[-5.85 ; 3.31]$} & -3.23 & {$[-7.5$} & 83] & \\
\hline $\mathrm{C}-\mathrm{F}-\mathrm{AB}$ & -.01 & -.43 & .667 & {$[-.03 ; .02]$} & -.03 & {$[-.07$} & 03] & \\
\hline $\mathrm{C}-\mathrm{F}-\mathrm{W}$ & -1.77 & -.89 & .380 & {$[-5.78 ; 2.24]$} & -2.73 & {$[-6.5$} & 33] & \\
\hline \multicolumn{9}{|l|}{ Older adults } \\
\hline & \multicolumn{4}{|l|}{ Path a } & \multicolumn{4}{|l|}{ Path b } \\
\hline & $\beta$ & $t$ & $p$ & $\mathrm{CI}$ & $\beta$ & $t$ & $p$ & $\mathrm{CI}$ \\
\hline $\mathrm{N}-\mathrm{F}-\mathrm{W}$ & -39.65 & -8.34 & $<.001$ & {$[-49.18 ;-30.12]$} & .34 & 5.54 & $<.001$ & {$[.22 ; .46]$} \\
\hline$E-A-W$ & 2.36 & 2.78 & .007 & {$[.66 ; 4.07]$} & 1.34 & 4.33 & $<.001$ & {$[.72 ; 1.96]$} \\
\hline$C-A-A B$ & 3.75 & 2.72 & .009 & {$[.98 ; 6.51]$} & .01 & 3.72 & .001 & {$[.004 ; .01]$} \\
\hline $\mathrm{C}-\mathrm{A}-\mathrm{W}$ & 3.57 & 2.56 & .013 & {$[.78 ; 6.36]$} & 1.15 & 3.38 & .001 & {$[.46 ; 1.83]$} \\
\hline $\mathrm{C}-\mathrm{F}-\mathrm{AB}$ & 33.60 & 5.52 & $<.001$ & {$[21.18 ; 46.03]$} & .002 & 7.87 & $<.001$ & {$[.002 ; .003]$} \\
\hline \multirow[t]{3}{*}{$\mathrm{C}-\mathrm{F}-\mathrm{W}$} & 35.10 & 5.75 & $<.001$ & {$[22.87 ; 47.34]$} & .22 & 4.85 & $<.001$ & {$[.13 ; .31]$} \\
\hline & \multicolumn{4}{|c|}{ Path c' } & \multicolumn{4}{|c|}{ Path c $-c^{\prime}$} \\
\hline & $\beta$ & $t$ & $p$ & $\mathrm{CI}$ & Effect & $\mathrm{CI}$ & & \\
\hline $\mathrm{N}-\mathrm{F}-\mathrm{W}$ & 6.89 & 2.15 & .036 & {$[.47 ; 13.31]$} & -13.43 & {$[-19$.} & $-8.49]$ & \\
\hline$E-A-W$ & .36 & .17 & .869 & {$[-4.03 ; 4.76]$} & 3.17 & {$[1.21$} & 09] & \\
\hline$C-A-A B$ & .04 & 2.13 & .038 & {$[.002 ; .07]$} & .03 & {$[.01 ;$} & & \\
\hline $\mathrm{C}-\mathrm{A}-\mathrm{W}$ & 6.39 & 2.20 & .032 & {$[.57 ; 12.22]$} & 4.08 & {$[1.51$} & 91] & \\
\hline$C-F-A B$ & -.01 & -.39 & .702 & {$[-.03 ; .02]$} & .07 & {$[.04$} & & \\
\hline $\mathrm{C}-\mathrm{F}-\mathrm{W}$ & 2.79 & 1.12 & .268 & {$[-2.21 ; 7.80]$} & 7.69 & {$[4.64$} & $.40]$ & \\
\hline
\end{tabular}

Note . Bold $=$ Mediation, Italic $=$ Full Mediation. $\mathrm{CI}=95 \%$ confidence interval, $\mathrm{N}=$ neuroticism, $\mathrm{E}=$ extraversion, $\mathrm{C}=$ conscientiousness, $\mathrm{A}$

$=$ score on the AAQ-II, $\mathrm{F}=$ score on the FIT $-60, \mathrm{AB}=$ affect balance, $\mathrm{W}=$ WHOQOL-Bref. Path $\mathrm{a}=$ effect personality on flexibility. Path $\mathrm{b}$

$=$ effect flexibility on well-being. Path $c^{\prime}=$ direct effect personality on well-being. Path $c-c^{\prime}=$ indirect effect of personality on well-being. 
RUNNING HEAD: Personality, Flexibility and Well-Being

Table 5

Correlations between all variables per age group.

\begin{tabular}{|c|c|c|c|c|c|c|c|c|c|}
\hline \multicolumn{10}{|c|}{ Younger adults } \\
\hline & $\mathrm{N}$ & $\mathrm{E}$ & $\mathrm{C}$ & NE & 1P & $\mathrm{A}$ & $\mathrm{F}$ & PI & $\mathrm{AB}$ \\
\hline $\mathrm{N}$ & 1 & & & & & & & & \\
\hline $\mathrm{E}$ & $\begin{array}{l}-.32 \\
(.012)\end{array}$ & 1 & & & & & & & \\
\hline $\mathrm{C}$ & $\begin{array}{l}.25 \\
(.053)\end{array}$ & $\begin{array}{l}-.08 \\
(.528)\end{array}$ & 1 & & & & & & \\
\hline $\mathrm{NE}$ & $\begin{array}{l}.71 \\
(<.001)\end{array}$ & $\begin{array}{l}-.06 \\
(.679)\end{array}$ & $\begin{array}{l}.38 \\
(.003)\end{array}$ & 1 & & & & & \\
\hline $\mathrm{IP}$ & $\begin{array}{l}.45 \\
(<.001)\end{array}$ & $\begin{array}{l}-.62 \\
(<.001)\end{array}$ & $\begin{array}{l}.34 \\
(.008)\end{array}$ & $\begin{array}{l}.31 \\
(.016)\end{array}$ & 1 & & & & \\
\hline A & $\begin{array}{l}-.45 \\
(<.001)\end{array}$ & $\begin{array}{l}-.07 \\
(.602)\end{array}$ & $\begin{array}{l}-.36 \\
(.005)\end{array}$ & $\begin{array}{l}-.58 \\
(<.001)\end{array}$ & $\begin{array}{l}-.22 \\
(.096)\end{array}$ & 1 & & & \\
\hline $\mathrm{F}$ & $\begin{array}{l}-.56 \\
(<.001)\end{array}$ & $\begin{array}{l}.22 \\
(.097)\end{array}$ & $\begin{array}{l}-.28 \\
(.029)\end{array}$ & $\begin{array}{l}-.71 \\
(<.001)\end{array}$ & $\begin{array}{l}-.40 \\
(.002)\end{array}$ & $\begin{array}{l}.71 \\
(<.001)\end{array}$ & 1 & & \\
\hline PI & $\begin{array}{l}-.22 \\
(.096)\end{array}$ & $\begin{array}{l}.04 \\
(.743)\end{array}$ & $\begin{array}{l}.11 \\
(.412)\end{array}$ & $\begin{array}{l}-.28 \\
(.033)\end{array}$ & $\begin{array}{l}-.01 \\
(.955)\end{array}$ & $\begin{array}{l}.10 \\
(.470)\end{array}$ & $\begin{array}{l}.13 \\
(.313)\end{array}$ & 1 & \\
\hline $\mathrm{AB}$ & $\begin{array}{l}-.80 \\
(<.001)\end{array}$ & $\begin{array}{l}.30 \\
(.020)\end{array}$ & $\begin{array}{l}-.25 \\
(.057)\end{array}$ & $\begin{array}{l}-.72 \\
(<.001)\end{array}$ & $\begin{array}{l}-.48 \\
(<.001)\end{array}$ & $\begin{array}{l}.58 \\
(<.001)\end{array}$ & $\begin{array}{l}.74 \\
(<.001)\end{array}$ & $\begin{array}{l}.12 \\
(.373)\end{array}$ & 1 \\
\hline $\mathrm{W}$ & $\begin{array}{l}-.49 \\
(<.001)\end{array}$ & $\begin{array}{l}.07 \\
(.609) \\
\end{array}$ & $\begin{array}{l}-.27 \\
(.035)\end{array}$ & $\begin{array}{l}-.59 \\
(<.001)\end{array}$ & $\begin{array}{l}-.30 \\
(.018)\end{array}$ & $\begin{array}{l}.57 \\
(<.001) \\
\end{array}$ & $\begin{array}{l}.62 \\
(<.001)\end{array}$ & $\begin{array}{l}.20 \\
(.124) \\
\end{array}$ & $\begin{array}{l}.62 \\
(<.001) \\
\end{array}$ \\
\hline \multicolumn{10}{|c|}{ Older adults } \\
\hline & $\mathrm{N}$ & $\mathrm{E}$ & $\mathrm{C}$ & $\mathrm{NE}$ & $1 \mathrm{P}$ & A & $\mathrm{F}$ & PI & $\mathrm{AB}$ \\
\hline $\mathrm{N}$ & 1 & & & & & & & & \\
\hline $\mathrm{E}$ & $\begin{array}{l}-.28 \\
(.034)\end{array}$ & 1 & & & & & & & \\
\hline $\mathrm{C}$ & $\begin{array}{l}-.38 \\
(.004)\end{array}$ & $\begin{array}{l}.51 \\
(<.001)\end{array}$ & 1 & & & & & & \\
\hline $\mathrm{NE}$ & $\begin{array}{l}.71 \\
(.001)\end{array}$ & $\begin{array}{l}-.15 \\
(.265)\end{array}$ & $\begin{array}{l}-.18 \\
(.179)\end{array}$ & 1 & & & & & \\
\hline $1 \mathrm{P}$ & $\begin{array}{l}.05 \\
(.693)\end{array}$ & $\begin{array}{l}-.40 \\
(.002)\end{array}$ & $\begin{array}{l}-.10 \\
(.474)\end{array}$ & $\begin{array}{l}.08 \\
(.566)\end{array}$ & 1 & & & & \\
\hline A & $\begin{array}{l}-.53 \\
(<.001)\end{array}$ & $\begin{array}{l}.33 \\
(.012)\end{array}$ & $\begin{array}{l}.36 \\
(.006)\end{array}$ & $\begin{array}{l}-.38 \\
(.003)\end{array}$ & $\begin{array}{l}-.09 \\
(.497)\end{array}$ & 1 & & & \\
\hline $\mathrm{F}$ & $\begin{array}{l}-.73 \\
(<.001)\end{array}$ & $\begin{array}{l}.42 \\
(.001)\end{array}$ & $\begin{array}{l}.51 \\
(<.001)\end{array}$ & $\begin{array}{l}-.62 \\
(<.001)\end{array}$ & $\begin{array}{l}-.18 \\
(.176)\end{array}$ & $\begin{array}{l}.67 \\
(<.001)\end{array}$ & 1 & & \\
\hline PI & $\begin{array}{l}-.03 \\
(.838)\end{array}$ & $\begin{array}{l}-.23 \\
(.086)\end{array}$ & $\begin{array}{l}-.08 \\
(.584)\end{array}$ & $\begin{array}{l}-.11 \\
(.443)\end{array}$ & $\begin{array}{l}-.15 \\
(.292)\end{array}$ & $\begin{array}{l}-.19 \\
(.176)\end{array}$ & $\begin{array}{l}.01 \\
(.937)\end{array}$ & 1 & \\
\hline $\mathrm{AB}$ & $\begin{array}{l}-.73 \\
(<.001)\end{array}$ & $\begin{array}{l}.43 \\
(.001)\end{array}$ & $\begin{array}{l}.38 \\
(.003)\end{array}$ & $\begin{array}{l}-.69 \\
(.001)\end{array}$ & $\begin{array}{l}-.23 \\
(.088)\end{array}$ & $\begin{array}{l}.56 \\
(<.001)\end{array}$ & $\begin{array}{l}.79 \\
(<.001)\end{array}$ & $\begin{array}{l}.08 \\
(.546)\end{array}$ & 1 \\
\hline W & $\begin{array}{l}-.33 \\
(.014)\end{array}$ & $\begin{array}{l}.19 \\
(.158)\end{array}$ & $\begin{array}{l}.42 \\
(.001)\end{array}$ & $\begin{array}{l}-.35 \\
(.009)\end{array}$ & $\begin{array}{l}-.10 \\
(.460)\end{array}$ & $\begin{array}{l}.57 \\
(<.001)\end{array}$ & $\begin{array}{l}.64 \\
(<.001)\end{array}$ & $\begin{array}{l}.01 \\
(.941)\end{array}$ & $\begin{array}{l}.50 \\
(<.001)\end{array}$ \\
\hline
\end{tabular}

Note. $r(p$-value). $\mathrm{N}=$ neuroticism, $\mathrm{E}=$ extraversion, $\mathrm{C}=$ conscientiousness, $\mathrm{NE}=$ negative emotionality, $\mathrm{IP}=$ low positive emotionality, $\mathrm{A}=$ score on the AAQ-II, F = score on the FIT-60, PI = choice flexibility, AB = affect balance, W = WHOQOL-Bref. 
RUNNING HEAD: Personality, Flexibility and Well-Being

Table 6

Indirect effects with psychological flexibility in total group.

\begin{tabular}{|c|c|c|c|c|c|c|c|c|}
\hline \multicolumn{9}{|c|}{ Choice Flexibility - Choice Task } \\
\hline & \multicolumn{4}{|c|}{ Path a } & \multicolumn{4}{|l|}{ Path b } \\
\hline & $\beta$ & $t$ & $p$ & $\mathrm{CI}$ & $\beta$ & $t$ & $p$ & $\mathrm{CI}$ \\
\hline $\mathrm{N}-\mathrm{PI}-\mathrm{AB}$ & -.01 & -.69 & .490 & {$[-.05 ; .02]$} & .01 & .35 & .731 & {$[-.07 ; .09]$} \\
\hline $\mathrm{N}-\mathrm{PI}-\mathrm{W}$ & -.01 & -.73 & .465 & {$[-.05 ; .02]$} & 2.98 & .37 & .715 & {$[-13.15 ; 19.11]$} \\
\hline$E-P I-A B$ & -.03 & -1.20 & .233 & {$[-.07 ; .02]$} & .08 & 1.54 & .127 & {$[-.02 ; .19]$} \\
\hline$E-P I-W$ & -.03 & -1.10 & .272 & {$[-.07 ; .02]$} & 7.06 & .75 & .453 & {$[-11.52 ; 25.64]$} \\
\hline $\mathrm{C}-\mathrm{PI}-\mathrm{AB}$ & -.001 & -.07 & .948 & {$[-.04 ; .04]$} & .05 & .89 & .374 & {$[-.06 ; .15]$} \\
\hline $\mathrm{C}-\mathrm{PI}-\mathrm{W}$ & .003 & .01 & .989 & {$[-.04 ; .04]$} & 5.26 & .60 & .551 & {$[-12.16 ; 22.67]$} \\
\hline $\mathrm{NE}-\mathrm{PI}-\mathrm{AB}$ & -.01 & -1.85 & .066 & {$[-.01 ; .0003]$} & -.03 & -.74 & .462 & {$[-.11 ; .05]$} \\
\hline $\mathrm{NE}-\mathrm{PI}-\mathrm{W}$ & -.01 & -1.88 & .063 & {$[-.01 ; .0003]$} & -1.20 & -.17 & .866 & {$[-15.28 ; 12.89]$} \\
\hline$\overline{1 P}-\mathrm{PI}-\mathrm{AB}$ & -.003 & -.96 & .337 & {$[-.01 ; .003]$} & .03 & .46 & .646 & {$[-.08 ; .14]$} \\
\hline \multirow[t]{3}{*}{$1 \mathrm{P}-\mathrm{PI}-\mathrm{W}$} & -.003 & -.95 & .346 & {$[-.01 ; .003]$} & 3.89 & .44 & .662 & {$[-13.66 ; 21.44]$} \\
\hline & \multicolumn{4}{|c|}{ Path c' } & \multicolumn{4}{|c|}{ Path c-c' } \\
\hline & $\beta$ & $t$ & $p$ & CI & Effect & $\mathrm{CI}$ & & \\
\hline $\mathrm{N}-\mathrm{PI}-\mathrm{AB}$ & -.10 & -12.71 & $<.001$ & {$[-.12 ;-.09]$} & -.0002 & {$[-.00$} & .001] & \\
\hline $\mathrm{N}-\mathrm{PI}-\mathrm{W}$ & -6.67 & -4.06 & $<.001$ & {$[-9.93 ;-3.41]$} & -.04 & {$[-.71$} & & \\
\hline$E-P I-A B$ & .05 & 4.35 & $<.001$ & {$[.03 ; .07]$} & -.002 & {$[-.01$} & 01] & \\
\hline$E-P I-W$ & 2.50 & 1.54 & .127 & {$[-.72 ; 5.72]$} & -.18 & {$[-1.2$} & 16] & \\
\hline $\mathrm{C}-\mathrm{PI}-\mathrm{AB}$ & .01 & .58 & .564 & {$[-.02 ; .04]$} & -.0001 & {$[-.00$} & .003] & \\
\hline $\mathrm{C}-\mathrm{PI}-\mathrm{W}$ & 1.78 & .77 & .445 & {$[-2.84 ; 6.37]$} & .002 & {$[-.38$} & & \\
\hline $\mathrm{NE}-\mathrm{PI}-\mathrm{AB}$ & -.02 & -9.72 & $<.001$ & {$[-.02 ;-.01]$} & .0001 & {$[-.00$} & $.001]$ & \\
\hline $\mathrm{NE}-\mathrm{PI}-\mathrm{W}$ & -1.27 & -5.02 & $<.001$ & {$[-1.77 ;-.77]$} & .01 & {$[-.07$} & & \\
\hline $\mathrm{IP}-\mathrm{PI}-\mathrm{AB}$ & -.01 & -3.58 & $<.001$ & {$[-.01 ;-.004]$} & -.0001 & {$[-.00$} & $0002]$ & \\
\hline $1 \mathrm{P}-\mathrm{PI}-\mathrm{W}$ & -.59 & -1.70 & .092 & {$[-1.27 ; .10]$} & -.01 & {$[-.13$} & & \\
\hline
\end{tabular}

Note. $\mathrm{CI}=95 \%$ confidence interval, $\mathrm{N}=$ neuroticism, $\mathrm{E}=$ extraversion, $\mathrm{C}=$ conscientiousness, $\mathrm{NE}=$ negative emotionality, $\mathrm{lP}=$ low positive emotionality, $\mathrm{PI}=$ choice flexibility,, $\mathrm{AB}=$ affect balance, $\mathrm{W}=$ WHOQOL-Bref. Path $\mathrm{a}=$ effect personality on flexibility. Path $\mathrm{b}=$ effect

flexibility on well-being. Path c' $=$ direct effect personality on well-being. Path $c^{-} c^{\prime}=$ indirect effect of personality on well-being. 
RUNNING HEAD: Personality, Flexibility and Well-Being

Table 7

Interactions of age on the different steps in the indirect effect analyses.

\begin{tabular}{|c|c|c|c|c|c|c|c|c|}
\hline \multicolumn{9}{|c|}{ Choice Flexibility - Choice Task } \\
\hline & \multicolumn{4}{|c|}{ Path a } & \multicolumn{4}{|l|}{ Path b } \\
\hline & $\beta$ & $t$ & $p$ & $\mathrm{CI}$ & $\beta$ & $t$ & $p$ & CI \\
\hline $\mathrm{N}-\mathrm{PI}-\mathrm{AB}$ & .03 & .70 & .484 & {$[-.05 ; .10]$} & .09 & 1.04 & .301 & {$[-.08 ; .25]$} \\
\hline $\mathrm{N}-\mathrm{PI}-\mathrm{W}$ & .02 & .61 & .541 & {$[-.05 ; .10]$} & -9.73 & -.63 & .532 & {$[-40.46 ; 21.01]$} \\
\hline$E-P I-A B$ & -.06 & -1.31 & .19 & {$[-.15 ; .03]$} & .02 & .20 & .840 & {$[-.22 ; .27]$} \\
\hline $\mathrm{E}-\mathrm{PI}-\mathrm{W}$ & -.05 & -1.17 & .245 & {$[-.14 ; .04]$} & -14.49 & -.81 & .417 & {$[-49.75 ; 20.78]$} \\
\hline $\mathrm{C}-\mathrm{PI}-\mathrm{AB}$ & -.04 & -1.03 & .304 & {$[-.12 ; .04]$} & -.06 & -.47 & .638 & {$[-.29 ; .18]$} \\
\hline $\mathrm{C}-\mathrm{PI}-\mathrm{W}$ & -.04 & -.90 & .368 & {$[-.12 ; .04]$} & -19.35 & -1.12 & .221 & {$[-50.48 ; 11.79]$} \\
\hline $\mathrm{NE}-\mathrm{PI}-\mathrm{AB}$ & .003 & .46 & .650 & {$[-.01 ; .01]$} & .08 & .90 & .368 & {$[-.09 ; .25]$} \\
\hline$N E-P I-W$ & .002 & .41 & .684 & {$[-.01 ; .01]$} & -6.34 & -.46 & .643 & {$[-33.38 ; 20.71]$} \\
\hline$\overline{1 P-P I-A B}$ & -.01 & -1.02 & .310 & {$[-.02 ; .01]$} & -.07 & -.54 & .590 & {$[-.32 ; .18]$} \\
\hline \multirow[t]{3}{*}{$\mathrm{IP}-\mathrm{PI}-\mathrm{W}$} & -.01 & -.99 & .327 & {$[-.02 ; .01]$} & -19.47 & -1.16 & .249 & {$[-52.79 ; 13.84]$} \\
\hline & \multicolumn{4}{|c|}{ Path c' } & \multicolumn{4}{|c|}{$\begin{array}{l}\text { Index of moderated mediation: } \\
\text { path c - c' }\end{array}$} \\
\hline & $\beta$ & $t$ & $p$ & $\mathrm{CI}$ & Index & $\mathrm{CI}$ & & \\
\hline $\mathrm{N}-\mathrm{PI}-\mathrm{AB}$ & .002 & .09 & .925 & {$[-.03 ; .03]$} & -.002 & {$[-.01$} & & \\
\hline $\mathrm{N}-\mathrm{PI}-\mathrm{W}$ & .42 & .11 & .909 & {$[-6.83 ; 7.66]$} & .32 & {$[-.66$} & & \\
\hline$E-P I-A B$ & .03 & 1.06 & .290 & {$[-.02 ; .07]$} & -.01 & {$[-.03$} & & \\
\hline$E-P I-W$ & 3.02 & .894 & .373 & {$[-3.67 ; 9.71]$} & -.33 & {$[-2.94$} & & \\
\hline $\mathrm{C}-\mathrm{PI}-\mathrm{AB}$ & .12 & 4.08 & $<.001$ & {$[.06 ; .17]$} & -.004 & {$[-.02$} & & \\
\hline $\mathrm{C}-\mathrm{PI}-\mathrm{W}$ & 16.00 & 4.24 & $<.001$ & {$[8.52 ; 23.49]$} & -.48 & {$[-2.4$} & & \\
\hline $\mathrm{NE}-\mathrm{PI}-\mathrm{AB}$ & -.001 & -.34 & .732 & {$[-.01 ; .01]$} & -.001 & {$[-.002$} & 01] & \\
\hline $\mathrm{NE}-\mathrm{PI}-\mathrm{W}$ & .14 & .26 & .794 & {$[-.94 ; 1.23]$} & .04 & {$[-.12 ;$} & & \\
\hline $\mathrm{P}-\mathrm{PI}-\mathrm{AB}$ & .003 & .63 & .530 & {$[-.01 ; .01]$} & -.0002 & {$[-.002$} & 01] & \\
\hline $1 \mathrm{P}-\mathrm{PI}-\mathrm{W}$ & .28 & .33 & .742 & {$[-1.41 ; 1.97]$} & .01 & {$[-.19$; } & & \\
\hline
\end{tabular}

Note. Bold $=$ Moderation-effect of age. $\mathrm{CI}=95 \%$ confidence interval, $\mathrm{N}=$ neuroticism, $\mathrm{E}=$ extraversion, $\mathrm{C}=$ conscientiousness, $\mathrm{NE}=$ negative emotionality, $\mathrm{IP}=$ low positive emotionality, $\mathrm{PI}=$ choice flexibility, $\mathrm{AB}=$ affect balance, $\mathrm{W}=\mathrm{WHOQOL}-\mathrm{Bref}$. Path $\mathrm{a}=$ effect personality on flexibility. Path $\mathrm{b}=$ effect flexibility on well-being. Path $\mathrm{c}^{\prime}=$ direct effect personality on well-being. Path $\mathrm{c}-\mathrm{c}^{\prime}=$ indirect effect of personality on well-being. 
RUNNING HEAD: Personality, Flexibility and Well-Being

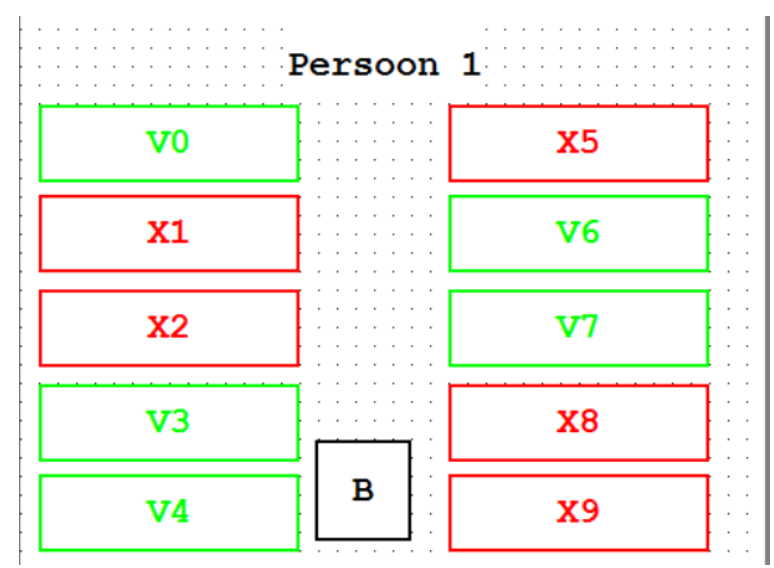

Figure 1. Screen 1 in the choice task. 


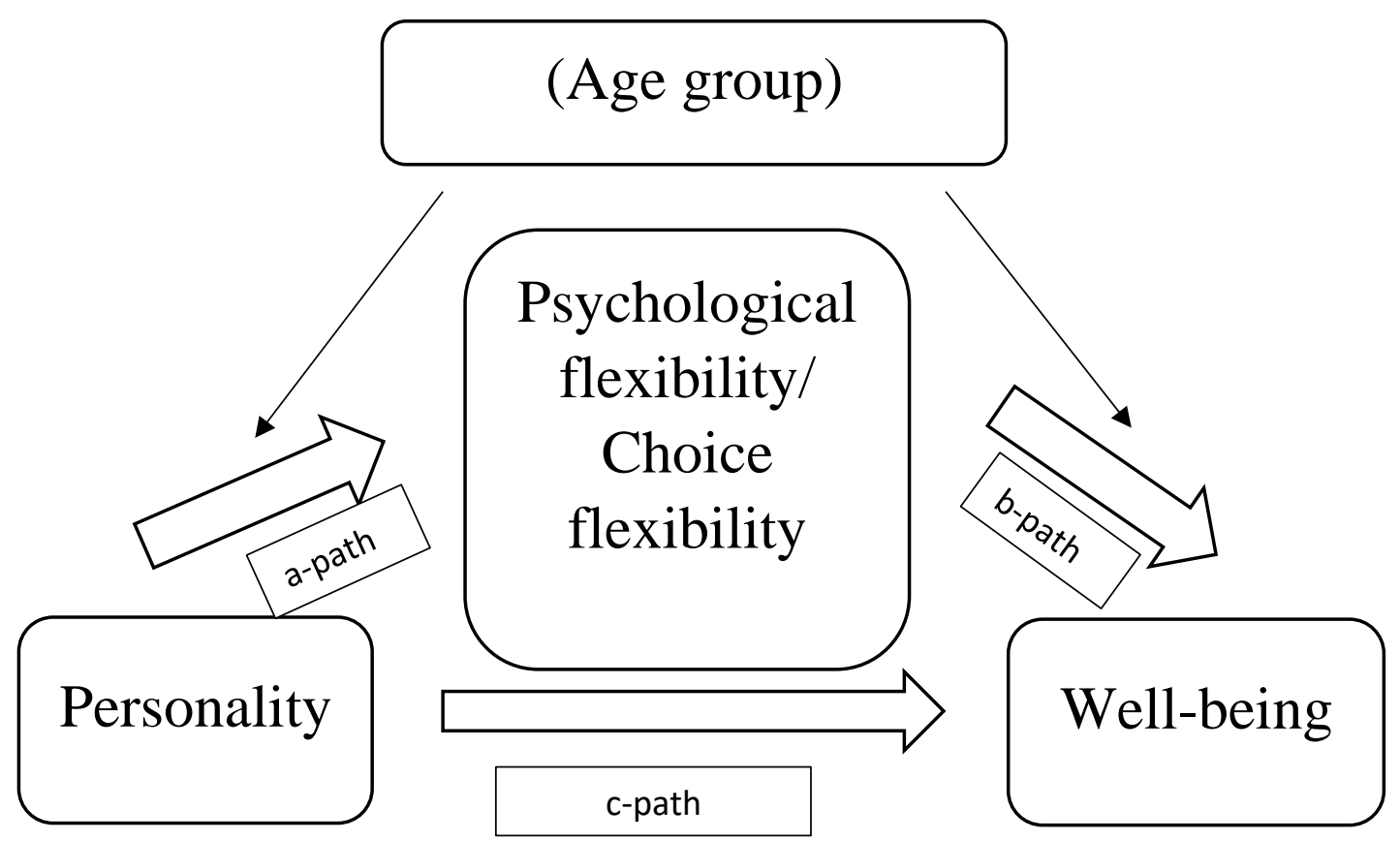

Figure 2. (Moderated) Mediation analysis. 